\title{
Mythos
}

MYTHOS

Rivista di Storia delle Religioni

$14 \mid 2020$

Varia

\section{Aristophanes and the Cult of the Saviour}

Aristofane e il culto del salvatore

\section{Bruno Currie}

\section{(2) OpenEdition}

\section{Journals}

Electronic version

URL: https://journals.openedition.org/mythos/2088

DOI: $10.4000 /$ mythos. 2088

ISSN: 2037-7746

\section{Publisher}

Salvatore Sciascia Editore

Electronic reference

Bruno Currie, "Aristophanes and the Cult of the Saviour", Mythos [Online], 14 | 2020, Online since 31 December 2020, connection on 07 October 2021. URL: http://journals.openedition.org/mythos/2088 ; DOI: https://doi.org/10.4000/mythos.2088

This text was automatically generated on 7 October 2021.

Mythos 


\title{
Aristophanes and the Cult of the Saviour
}

Aristofane e il culto del salvatore

\author{
Bruno Currie
}

\section{Introduction}

1 The comedies of Aristophanes open up a significant perspective on heroization in ancient Greece, specifically in respect of the treatment of the saviour (sōtēr) as a more than human figure or, in standard scholarly parlance, a Gottmensch ${ }^{1}$. The concept of saving the community plays a part in several extant Aristophanic comedies. In Frogs, Dionysos' descent to the underworld to fetch Euripides turns into a quest for a poet who will "save the city" $(1419,1500-1503)$. In Lysistrata, the women's aim is to "save Greece" (29-30, 39-41, 525-526)2. However, three plays make very particular use of the concept of the civic sōtèr: Knights of $424 \mathrm{BCE}$, Peace of $421 \mathrm{BCE}$, and Birds of $414 \mathrm{BCE}^{3}$ These are the focus of the present paper.

2 The paper has six sections. Sections 1-3 aim to illustrate and evaluate the role that the saviour-figure plays in each of the three plays. Section 4 examines the blending of real religious elements with paratragic and metatheatrical elements that we find in the comic presentation of the saviour or Gottmensch. Section 5 undertakes to explain why the sōter- or Gottmensch-figure is properly a concern of old Comedy. Section 6, finally, explores the significance of the Aristophanic picture for our understanding of the early history of Gottmenschentum in ancient Greece.

\section{Birds}

We start with Birds, the latest of the three plays, as it offers the clearest illustration of a civic saviour being treated as a man become god. Peisetairos is hailed early on as the birds' sōtêr: "thanks to god and some good chance, I think, you have come as saviour to 
me" (544-545) ${ }^{4}$. The end of the play shows Peisetairos both receiving religious attentions from the community of birds and fully apotheosized (a man become god, therefore, via becoming a bird!) $)^{5}$. In the last words of the play, he is acclaimed as "highest of divine beings" (1765).

The closing scene of Birds (1706-1765) draws on several schemata found in the context of ruler-cult. First, there is the messenger's announcement of Peisetairos' imminent arrival. This speech (1706-1719), delivered with Peisetairos off-stage, has been convincingly likened to the announcement by a hierokerryx of the imminent epiphanic arrival of a deity or the arrival of a ruler and the concomitant exhortation of the populace to "receive" the deity or ruler appropriately (1706-1708)6 . An example involving a deity is the end of Callimachus' Bath of Pallas (137-139) ${ }^{7}$. An earlier example involving a human ruler-to-be is Herodotus' description of Peisistratos' re-entry in Athens in the mid-sixth century BCE (I 60) .

5 Second, the chariot entry. Immediately following the messenger's speech Peisetairos enters in a chariot ${ }^{9}$. He is treated to a makarismos by the birds and his marriage with the goddess BASILEIA is celebrated ${ }^{10}$. Kavoulaki points out that "[t]he procession performed is both victorious and bridal ${ }^{11}$." The conflation of victory procession and wedding procession is found elsewhere in the celebration of exceptional men ${ }^{12}$. One revealing example, involving a returning athletic victor, is provided by Pindar's ninth Pythian ode (c. $474 \mathrm{BCE}$ ), whose encomiastic imagery equates the athlete's triumphal return by chariot with a wedding procession ${ }^{13}$. The victor Telesikates is described as "leading lovely DOXA to his fatherland," Cyrene, where the eponymous nymph Kyrene will "receive" him joyously (73-75). This provides a pointed parallel to the mythical narrative of the ode: Apollo brought Kyrene as his bride in a chariot to Libya, where the pair were "received" by Aphrodite (5-13). Peisetairos receives comparably elevating treatment at the end of Birds.

6 Third, betrothal to a divine bride. Peisetairos' marriage to BASILEIA is explicitly modelled on the marriage of Zeus to Hera (1731-1735). According to the wisdom of archaic and classical choral lyric, marriage to a goddess was proverbially out of the reach of a mortal. For instance, Alcman fr. 1.17-20 PMGF: "do not attempt to wed Mistress Aphrodite or any [...] or a daughter of Porkos ${ }^{14}$." Or Pindar, Pythian IV 90-93: "Artemis' shaft hunted down Tityos swiftly, darting from her invincible quiver, in order that one should desire to lay one's hand on love affairs in the realm of the possible ${ }^{15}$." The exceptions acknowledged are significant: Peleus and Kadmos married goddesses and were granted an exceptional afterlife (Pindar, Pythian III 88-96; Olympian II 78); Herakles' marriage to HEBE is the culmination of his apotheosis (Pindar, Nemean I 71-72, Isthmian IV 59-60). In historical contexts, both Hellenistic and Roman, we hear of Demetrios Poliorketes being given "Athena" as a bride by the Athenians towards the end of the fourth century BCE (Clement of Alexandria, Protrepticus IV 54), and likewise Marcus Antonius in 39/8 BCE (Seneca, Suasoriae I 6; Cassius Dio XLVIII 39.2) ${ }^{16}$. Theopompus records the following story of the fourth-century BCE Odrysian (Thracian) king Kotys (FGrHist / BNJ 115 F31, in Athenaeus XII 531e-532a):

Kotys prepared a feast as though Athena was being wedded to him and after preparing the bridal chamber waited, drunk, for the goddess; and having already taken leave of his senses he dispatched one of his bodyguards to see if the goddess had come to the chamber, and when he returned and said that no-one was in the chamber, he shot him with an arrow and killed him, and a second one likewise, 
until the third, getting wise, said the goddess had come a while time ago and was waiting for him ${ }^{17}$.

7 These historical cases suggest that, as Weinreich put it, "what Alcman [sc. fr. 1.17-20 PMGF, cited above, \$6] warns against as the ultimate expression of felicity that is forbidden to normal men - that is precisely what the Gottmenschen of the Hellenistic period strove for and sought to realize already on earth ${ }^{18}$." The theme of marriage to a goddess evidently became a standard encomiastic motif attached to the Gottmensch. Rhianus of Bene in the third century BCE speaks of the man who is carried away by success as "betrothing himself to Athena" (I 14). Virgil's fourth Eclogue, celebrating the birth of a Heiland / saviour-figure, concludes with the comment that "the goddess does not consider worthy of her bed" those who have not smiled at their parent at their birth (63) - with the implication that partnership in the goddess' (sc. Athena's?) bed is a natural expectation for the saviour ${ }^{19}$. It has been suggested that, already in c. $550 \mathrm{BCE}$, Peisistratos with Phye was exploiting the "marriage to Athena" motif (Herodotus I $60.4-5)^{20}$. As early as the third millennium BCE, Sumerian kings were depicted as performing a "sacred marriage" ritual with Inanna, a tradition that may have been known to archaic Greeks ${ }^{21}$.

8 Fourth, impersonation of Zeus. Birds depicts Peisetairos as wielding Zeus' thunderbolt (1714). Striking impersonations of Zeus are reported for fourth-century-BCE Gottmensch-figures: Klearchos of Heraclea, "on becoming tyrant of Heraclea, took to wielding a sceptre [or, if we accept an emendation, "thunderbolt"] and called one of his sons Lightning" (Plutarch, On the Fortune or Valour of Alexander the Great 338b) ${ }^{22}$. Menekrates called himself "Zeus" and "went around wielding a sceptre" (Athenaeus VII 289c) ${ }^{23}$. The place where Demetrios Poliorketes descended from his chariot in Athens was consecrated to "Demetrios kataibates" and received an altar (Plutarch, Demetrius 10.5): places struck by lightning were consecrated to Zeus kataibates and provided with an altar $^{24}$. Already in Old Comedy, "Olympian" Perikles had been likened to Zeus, "lightning and thundering" (Aristophanes, Acharnians 530-531), apparently not just a jibe at Perikles' powerful oratory (Plutarch, Pericles 8.2-4), but a reflection of a popular notion that the immense power he wielded made him Zeus-like ${ }^{25}$. The philosopher Anaxarchos of Abdera, according to the third- or second-century BCE biographer Satyrus, asked Alexander the Great after a thunderclap whether he, the son of Zeus, could thunder like that (Satyrus fr. 26 Schorn = Anaxarchos fr. 72 A4 Diels-Kranz) ${ }^{26}$. Alexander was depicted wielding the thunderbolt in a (near-)contemporary painting by Apelles (Plutarch, Alexander 4.3; Pliny, Natural History XXXV 92) and on coins dating to Alexander's lifetime ${ }^{27}$. Callimachus' dictum, "it is not mine to thunder, but Zeus"' (Aetia fr. 1.20 Harder) seems wittily to conflate such impersonations of Zeus with the metaphorical sense of "thundering" found in rhetorical or literary critical contexts (this latter use also deriving from old Comedy: Aeschylus is "deep-thundering",

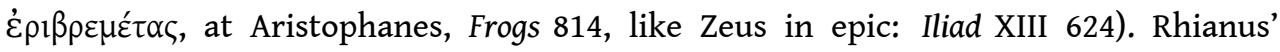
puffed-up man "thunders like Zeus" (I 13), and Virgil, in a passage possibly influenced by Rhianus, speaks of "Caesar the Great [sc. Augustus] thundering by the deep Euphrates" (Georgics IV 560-561), a phrase which conflates notions of the Zeusimpersonating ruler thundering with Callimachean literary critical notions ${ }^{28}$. If these last cases suggest a metaphorical understanding of "thundering", then the case of the mythical Salmoneus suggests that artificial simulations of thunder were possible (Apollodorus, Library I 9.7; Virgil, Aeneid VI 585-594; Manilius, V 91-96) ${ }^{29}$. The idea leant itself to parody already in the fifth century: Euripides' Cyclops equates his farting with 
Zeus' thunderbolt (Cyclops 328) ${ }^{30}$. All this is not to be divorced from fifth- and fourthcentury impersonations of Zeus (or of the gods more generally). Xerxes invading Greece is likened to Zeus (Herodotus VII 56.2; Gorgias 83 B5a Diels-Kranz). On the tragic stage, Rhesos is hailed as a Zeus made manifest (Pseudo-Euripides, Rhesus 355-356 oú

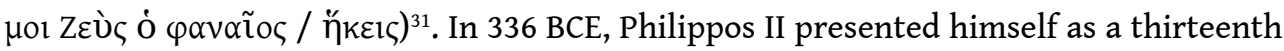
Olympian god in the theatre of Aegae (Diodorus XVI 92.5, XVI 95.1). This again infringes an epinician injunction against wishing to become Zeus (Pindar, Isthmian V 14, Olympian V 24). I have argued that such Pindaric gnomai "belong precisely in a context in which the possibility of heroization is being explored ${ }^{32}$." In several of these historical cases, the possibility of heroization (or apotheosis) was being explored in real life. Interesting here too are the implications of Pindar's pairing in Pythian 1 of Hieron with Zeus, specifically as wielder of the thunderbolt (5-30, especially 5-6 ${ }^{33}$.

Apart from these schemata of ruler cult, the Messenger's speech in Birds (1706-1719) is replete with language, images, and motifs that recur in the real experience of epiphany of gods and Gottmenschen ${ }^{34}$. The main ones are the following.

First, the "reception" motif: $1708 \delta \varepsilon$ ¿́ $\varepsilon \sigma \theta \varepsilon^{35}$. We have touched on the use of this verb, in the imperative form, in the context of the proclamation of a hierokerryx, preparing the community to "receive" the arriving deity or Gottmensch (see above, §§4-5). It is also found in the context of the "reception" by a community of worshippers of a deity arriving in epiphany at a festival in their honour (e.g. Poseidon, at the Isthmus: Pindar,

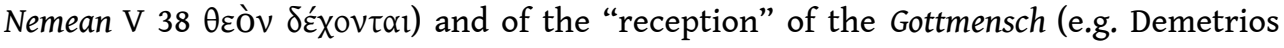
Poliorketes in Athens: Demochares FGrHist 75 F2 $=$ BNJ 75 F6) ${ }^{36}$.

11 Second, the "advent" motif (found, in conjunction with the preceding, in the epiphany

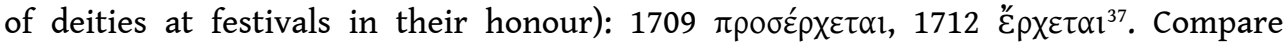

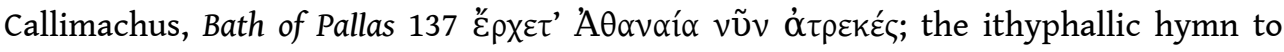

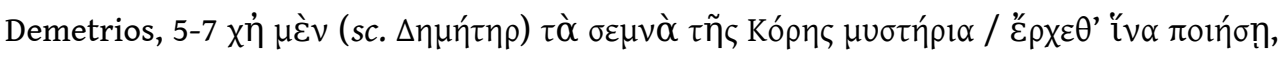
ò $\delta$ '... k $\tau$.

Third, solar and astral imagery: Peisetairos is said to outshine the stars and the sun: $1709-1712^{38}$. In a poem by one Hermodotos, Antigonos Monophthalmos was acclaimed as "son of Helios" and a "god" (Plutarch Isis and Osiris 360c) ${ }^{39}$. The ithyphallic hymn to Demetrios compared him to the sun and his associates to the stars (11-12) ${ }^{40}$. In Horace, Sermones I 7.22-25, one Persius, in a lawsuit with Rupilius Rex, called Brutus "the sun of Asia" and his associates "healthsome stars" (but Rupilius a "Dog-Star, hateful to farmers") ${ }^{41}$.

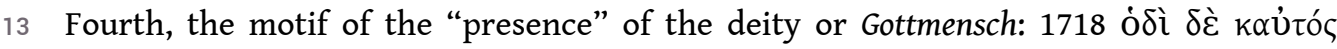

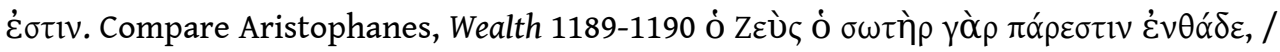

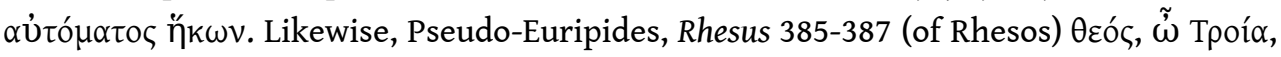

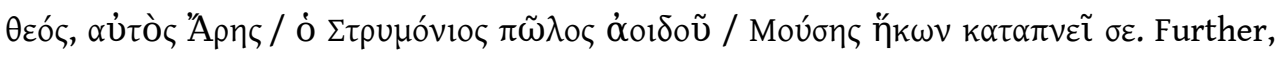

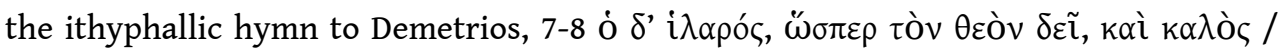

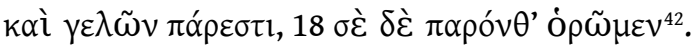

Overall, the effect of the scene consists in the co-presence of unreal (fantastical, absurd, theatrical) elements and of real practices derived from the treatment of epiphanic deities, of Gottmenschen, or of extraordinary men. There is a double distancing from reality in the scene, set in Cloudcuckooland and acted out in the comic theatre. But, as Kleinknecht and Versnel in particular have shown, there is a significant amount of 
"zooming" to real practices that could be, and were, applied to historical personages, both earlier (e.g. Peisistratos) and later (e.g. Demetrios Poliorketes) ${ }^{43}$.

\section{Knights}

Knights was produced ten years earlier than Birds, in 424 BCE. Early in the play, "Demosthenes" / "Servant 1" greets the Sausage-Seller on his first appearance as follows (147-150) $)^{44}$ :

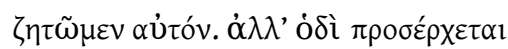

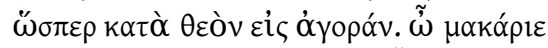

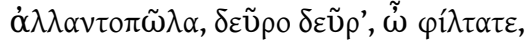

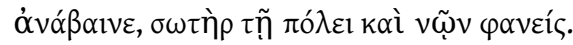

Let's go and find him. Well, here he is coming along,

as if heaven-sent, into the market-place. $O$ blessed

sausage-seller, come up here, here, o dearest fellow,

appearing as a saviour to the city and to the two of us.

According to Slater, "almost every word belongs to cult language ${ }^{45}$." We may point to the following phrases in particular.

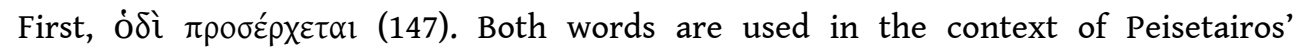

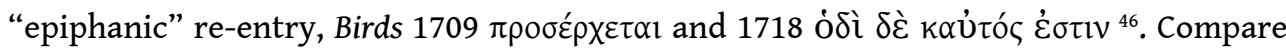
above $(\$ \$ 11,13)$ on the "advent" and "presence" motifs.

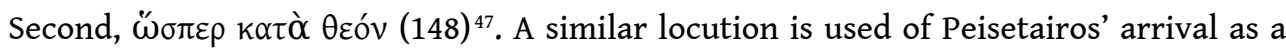

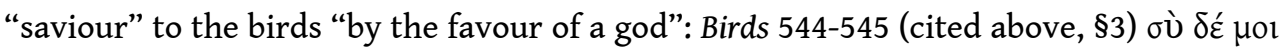

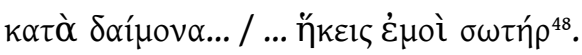

Third, $\delta \varepsilon \tilde{\mathbf{u}} \rho \circ \delta \varepsilon \tilde{\mathbf{u}} \rho$ ' (149). The same anadiplosis is found in a cletic invocation of Artemis

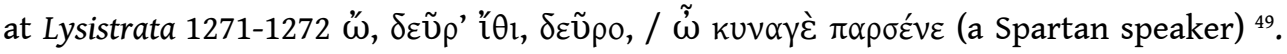
Compare also, in a cletic invocation to Hymen, Catullus LXI 8-9 huc / huc veni ${ }^{50}$.

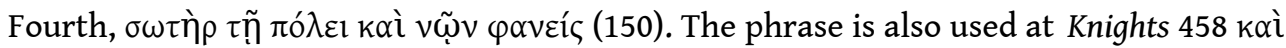

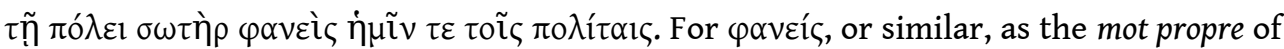

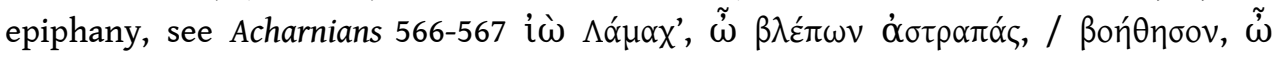

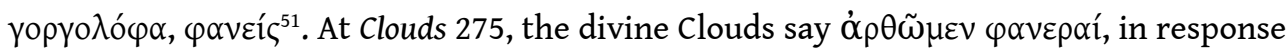

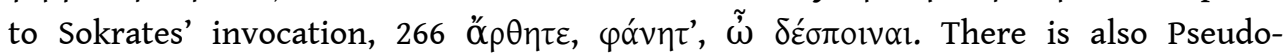

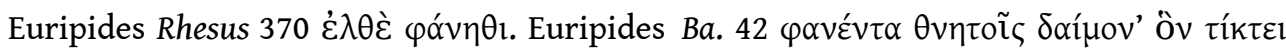

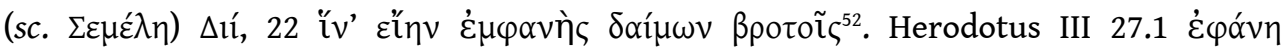

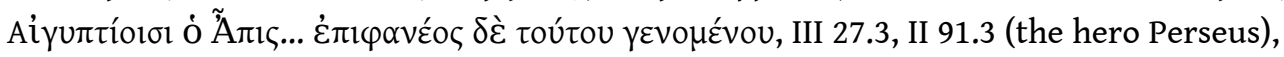

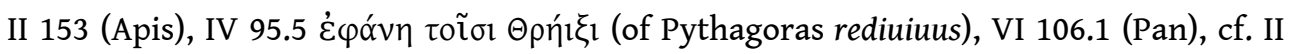

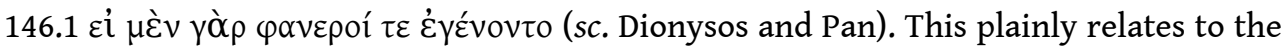
motif of the "presence" of the deity or Gottmensch in epiphany ${ }^{53}$.

It is clear that in Knights 147-150, "Demosthenes" / "Servant 1" hails the Sausage-Seller as a "saviour" in language typical for an epiphany. The idea of the Sausage-Seller as a Gottmensch is developed at Knights 836-840, where the coryphaeus says the following to the Sausage-Seller:

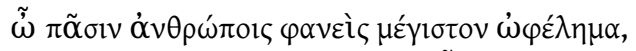

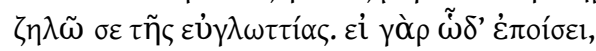

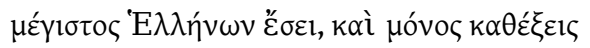

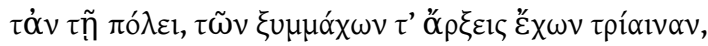




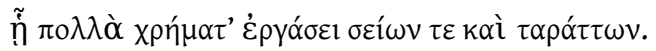

You who have appeared as the greatest boon to all men -

I envy you your eloquence. For if you are to lay into him like this, you shall be the greatest of the Greeks, and you alone shall be master of affairs in the city and shall rule the allies wielding the trident,

with which you shall make heaps of money, shaking and stirring ${ }^{54}$.

The passage continues the theme of the Sausage-Seller as an epiphanic (note paveís)

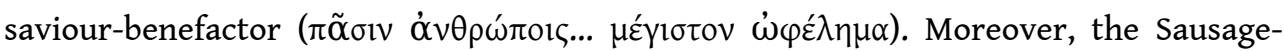
Seller, envisaged as ruling the allies with the trident, is now implicitly likened to Poseidon ${ }^{55}$. This verbal image of the Sausage-Seller as "Poseidon" should be compared to the on-stage appearance of Peisetairos in Birds as a "Zeus", wielding the thunderbolt $(1714,1748-1753)^{56}$. It also has affinities with the Old Comic image of Perikles as a thundering "Zeus" (see above, \$8).

23 In Birds, Peisetairos is hailed as sōter at the start and as "highest of the daimones" and ruler of the universe at the end of the play; in Knights, by contrast, the parallel promise of the Sausage-Seller's monarchical rule and apotheosis turns out to be a suggestio falsi, for the plot takes a surprising turn. When the Sausage-Seller re-enters at 1316, he unexpectedly plays the part not of the apotheosized sōter r, but of the hierokéryx, announcing to the chorus (and audience) the imminent appearance of DEMOS, whom he has "boiled down" and restored to his former glory ${ }^{57}$. Here are verses 1316-1318 and 1326-1328:

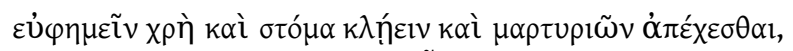

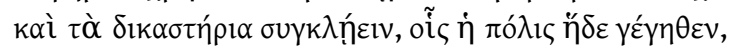

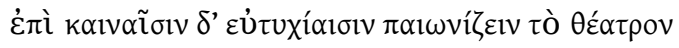

...

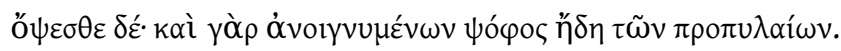

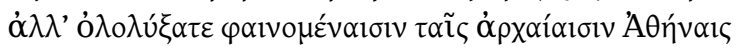

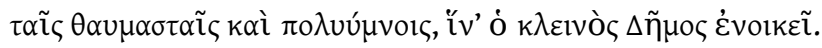

Please observe religious silence and bar your mouth and refrain from giving

evidence

and shut up the law courts in which this city delights

and let the theatre raise the paean-cry in recognition of brand new good fortune.

...

You shall see; for even now there is the noise of the gates being opened.

Come, ululate at the appearance of the Athens of old,

wondrous and much celebrated in song, where the well-known Demos dwells.

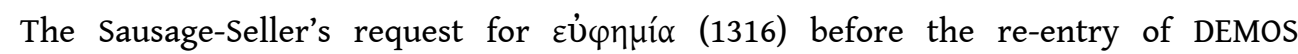
resembles that of the Messenger before the "epiphany" of Peisetairos at Birds $1719^{58}$. His request for the chorus of knights to ululate ( $\dot{\alpha} \lambda \lambda^{\prime}$ ' $\left.\lambda_{0} \lambda v^{\prime} \xi \alpha \tau \varepsilon\right)$ invites comparison

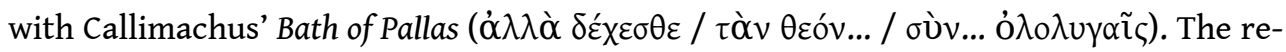
entry of DEMOS at the end of Knights, therefore, not that of the Sausage-Seller, corresponds to the re-entry of Peisetairos at the end of Birds. It is DEMOS now who is feted by the chorus of knights as "sole ruler" and "king of the Greeks" $(1330,1333)$, not the Sausage-Seller.

Kleinknecht argued that the re-entry of DEMOS in Knights is modelled on an epiphany of a deity or Gottmensch-figure, such as we see with Peisetairos in Birds (see above) ${ }^{59}$. Consider the following points. 

1715-1717. Both are attributes of deities or Gottmenschen, especially in an epiphany ${ }^{60}$. In the ithyphallic hymn, Demetrios is said to be "present, gracious, as a god should be, and beautiful and laughing" $(7-8)^{61}$.

, DEMOS receives the beautiful personified SPONDAI for his sexual gratification (1388-1394), as Peisetairos is betrothed to BASILEIA in Birds (and as Trygaios is to OPORA in Peace). (Note, however, that DEMOS is not married to the SPONDAI, and the divine status of the SPONDAI is somewhat less clear than that of BASILEIA and OPORA. ${ }^{62}$ Their beauty (Knights 1390) appears to have a divine quality, corresponding to that of BASILEIA (Birds 1713) and OPORA and THEORIA (Peace 524).

Third, the impression that DEMOS here has something like divine status would by fostered by a sense of "zooming" to religious reality: an apotheosized DEMOS is attested in Athens from c. $450 \mathrm{BCE}$ and depicted on Attic relief documents from at least c. 350 $\mathrm{BCE}^{63}$.

Knights refrains from explicitly calling DEMOS a god ${ }^{64}$. However, the Sausage-Seller's words to DEMOS at 1337-1338 may suggest that this is indeed how he is to be conceived:

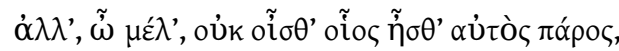

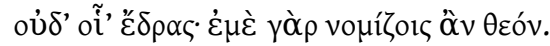

Ah, my good friend, you do not know the kind of person you yourself were formerly, or the kind of things you used to do; if you did, you would consider me a god.

The Sausage-Seller speaks, hyperbolically, of his own euergetism: "if you [sc. DEMOS] knew the extent of the service I have done you, you would consider me a god ${ }^{65}$." This particular hyperbole may be an idiomatic figure of speech ${ }^{66}$. But, however figuratively or hyperbolically meant, the Sausage-Seller's phrase "you would consider me a god" reverberates ironically and wittily with both the present situation, in which DEMOS is actually being treated as divine, and with the unrealized scenario previously envisaged by the coryphaeus in 837-840, where the Sausage-Seller was to be treated as a Gottmensch ("if you are to attack [Paphlagon] like this, you [the Sausage-Seller] shall be the greatest of the Greeks, and you shall rule the allies wielding a trident, etc.") ${ }^{67}$. The emphatic form $\dot{\varepsilon} \mu \varepsilon$ suggests the possibility of translating: "you would consider me a god", implying that DEMOS is the one who, as things stand, is being regarded as a god. The Sausage-Seller steps aside for DEMOS, unexpectedly making good here on his earlier disavowal of personal ambition (182).

Gottmenschentum plays a significant role in Knights as well as Birds. It is, of course, anachronistic to read Knights in the light of Birds, produced ten years later; but I submit that it is legitimate and illuminating to draw on Birds in order to reveal the plot pattern that underlies Knights. Knights, though earlier, is with its suggestio falsi the quirkier play in its deployment of the sōter / Gottmensch motif. This oblique treatment of the theme in Knights raises the possibility that plays with this kind of plot pattern had already preceded Knights. We shall see that the same plot pattern is in evidence also in Peace of $421 \mathrm{BCE}$, three years later than Knights. Both plays (plus Peace) could then be assumed to be drawing independently on a standard old Comic plot-pattern. Alternatively, Birds could be seen as responding specifically to (Peace and) Knights; on this scenario, Birds could show us how to read Knights, reading back up the line of reception (I have argued similarly that seeing how Sophocles represents the process of Oidipous' heroization in 
his latest extant play, Oedipus at Colonus, can help us to recognize a similar process of heroization with Aias in Ajax, his earliest extant play) ${ }^{68}$.

\section{Peace}

Peace intervenes chronologically between Knights and Birds. Trygaios is depicted as sōtēr three times in the play ${ }^{69}$. The first is 856-867:

Хo. $\quad \varepsilon \dot{\delta} \delta \alpha \iota \mu \nu v i \kappa \tilde{\omega} \varsigma \gamma^{\prime}$ ó $\pi \rho \varepsilon-$

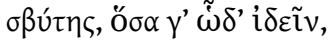

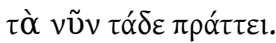

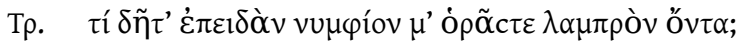

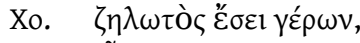
860

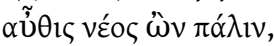

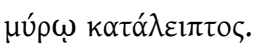

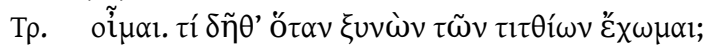

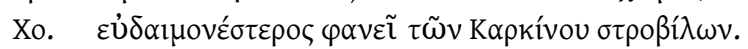

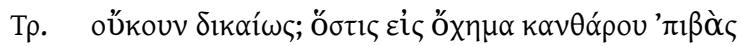

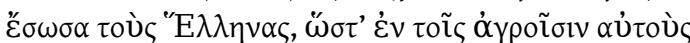

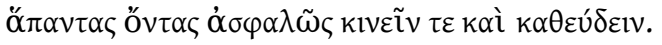

Chor.: The old man is faring happily, from all that we can see before us, in the present moment.

Tryg.: What about when you see me as a bridegroom, all resplendent?

Chor.: You shall be an old man to envy, being young once more, anointed with perfume.

Tryg.: I should say so. What about when I lie with her and fondle her boobs?

Chor.: You shall seem more fortunate than the pirouetting sons of Karkinos.

Tryg.: Haven't I earned it? I who mounted my riding-beetle and saved the Greeks, so that all of them, in their fields without danger, could bonk and sleep.

The description here of Trygaios at his anticipated wedding to OPORA resembles the description of DEMOS at his "epiphany" in Knights, produced three years earlier. Note the following three similarities. First, $\lambda \alpha \mu \pi \rho$ óv (859), of Trygaios, corresponds to Knights $1330 \lambda \alpha \mu \pi \rho$ ós, of DEMOS. Second, "being young once more" (860), of Trygaios, corresponds to Knights 1322 "I boiled down DEMOS for you and made him beautiful

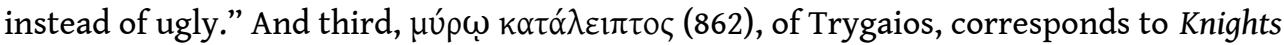

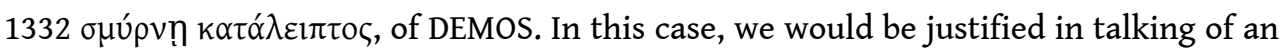
allusive intertextuality (reading, this, time, straightforwardly down the line of reception): the sōtèr-figure Trygaios in Peace of $421 \mathrm{BCE}$ can plausibly be taken to be modelled on (the rejuvenated, apotheosized) DEMOS in Knights of 424 BCE.

The second time that Trygaios is hailed as sōtēr is Peace $915^{70}$. Here are lines 909-921:

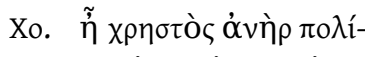
909-910

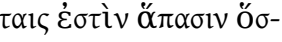

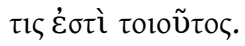

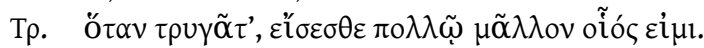

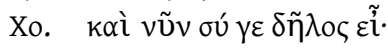

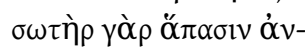

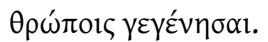

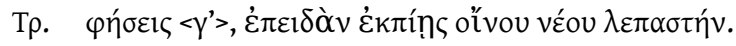




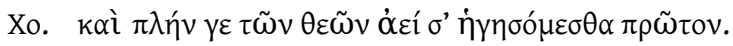

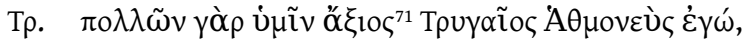

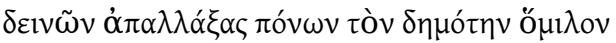

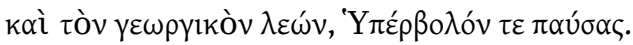

Chor.: In truth the man who is of such a nature does a service to all the citizens.

Tryg.: When you reap the fruit you will know my nature much better.

Chor.: Even now it is plain who you are: you have proven yourself a saviour to all men.

Tryg.: You'll say that all right when you drain your goblet of new wine.

Chor.: Indeed, we will forever consider you foremost, apart from the gods.

Tryg.: Truly you have me, Trygaios of the deme Athmonon, to thank for many things; I released from terrible troubles the people of the city and the folk who work the land, and I put an end to Hyperbolos. altars", with the scholiast's exegesis: "they have come to the altars established in front of the palace as to altars of a god") ${ }^{74}$. A little later in the speech we learn from the Priest that "this land calls you [sc. Oidipous] sōtēr for your former zeal" (47-48). The scene as a whole shows Oidipous receiving the Thebans' supplication (15-16, 31-32, 41) and a cletic invocation (46-47) ${ }^{75}$. In this, he resembles the gods of the city, Athena and Ismenian Apollo (19-21). Everything here points to Oidipous' being cast as the recipient of what we may see as a form of sōtêr- or ruler-cult. This would be mirrored by the posthumous hero cult that Oidipous receives at the end of the Oedipus at Colonus (as sōtèr: 459-460), a play clearly conceived as a sequel to the Oedipus Tyrannus. A non-Sophoclean reception of this opening of the Oedipus Tyrannus just over a century later is also highly relevant: the ithyphallic hymn to Demetrios Poliorketes alludes extensively at its end (20-34) to the opening scene of the Oedipus Tyrannus ${ }^{76}$. In the ithyphallic hymn, the Athenians "pray" (20) to their Gottmensch-saviour, Demetrios, a latter-day "Oidipous" (31-32) ${ }^{77}$, for him to protect them from a latter-day "Sphinx" (24), the Aetolians. The important point is that the author of the hymn is not merely styling Demetrios as a latter-day Oidipous, but also identifying Sophocles' Oidipous in Thebes as a forerunner of Demetrios in Athens: a Gottmensch-saviour, beneficiary of altars and prayers-cum- 
supplications from the populace ${ }^{78}$. (This argument relies, again, on the validity of reading back up the line of reception. $)^{79}$

Statements such as Oedipus Tyrannus 31-34 and Peace 917 do not straightforwardly express "conventional piety", if that is understood to rule out extending religious treatment to a human, to exclude the conception of the Gottmensch. We may think rather of what Levene, in the context of imperial Rome, has referred to as "the standard idea (important in maintaining the divine/human ambiguity in ruler cult) that one should not put oneself on a complete par with the gods", an idea which in no way entails "an objection to the idea of any sort of divine honour" being paid to the human ruler ${ }^{80}$. Oidipous in the opening scene of Oedipus Tyrannus is explicitly conceived as less than divine, but nevertheless as the deserving recipient of religious treatment such as the gods receive ${ }^{81}$. The chorus' pronouncements about Trygaios at Peace 913-915 and 917 as a "saviour" and as being "foremost apart from the gods" can be understood in a similar way.

It is worth briefly considering another passage, in which Trygaios is feted by a grateful Sickle-Maker whose peacetime trade is blooming (Peace 1198-1199):

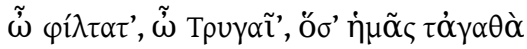

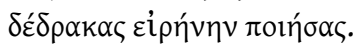

Dearest fellow, Trygaios, how many good turns

you have done us in making peace.

The first part of this sentence closely resembles the words of DEMOS to the Sausage-

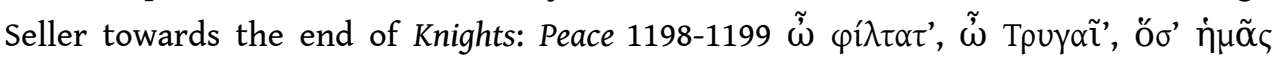

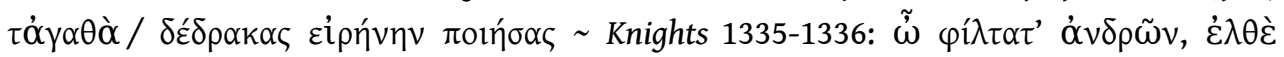

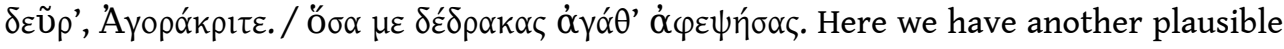
instance of allusive intertextuality between the two plays, with the important implication that Trygaios in Peace is constructed as a sōtēr- / benefactor-figure along the lines of the Sausage-Seller in Knights. The one phrase in these two lines of Peace that

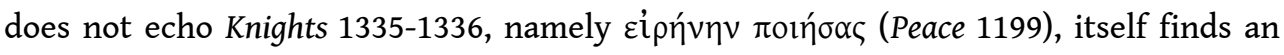

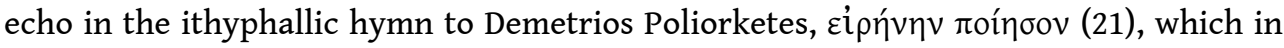

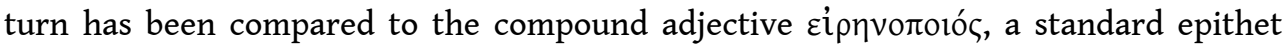
and concept in ruler- and imperial cult ${ }^{82}$. The parallels, both internal and external to Aristophanes, point consistently in the direction of ruler- or sōtēr-cult.

Trygaios also shows obvious traits of a Gottmensch in ascending to heaven, an exploit he has in common with Peisetairos in Birds (1686). The ascent to heaven violates another item of choral lyric wisdom ${ }^{83}$. We may note Alcman, "let no-one of men fly to the heaven" (fr. 1.16 PMGF) ${ }^{84}$. Or Pindar: "the brazen heaven is not mountable for him" (sc. the athletic victor) (Pythian X 27) ${ }^{85}$. Isthmian VII 43-48 instances Bellerophon as a mythological negative example, the same hero who, in his Euripidean incarnation, serves as positive example for Trygaios (Peace 76, and often). The attempt to ascend to heaven appears to be a motif standardly attached to Gottmenschen. Note, again, Rhianus'

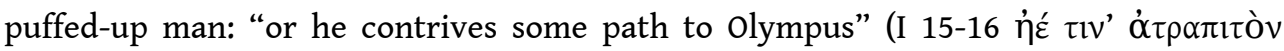

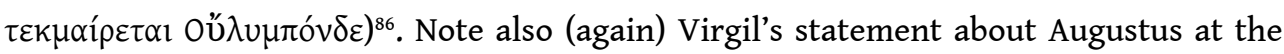
end of the Georgics: "and he attempts a path to Olympus" (IV 562 uiamque affectat Olympo, sc. Caesar; compare I $24-42$, especially $34-35)^{87}$. Virgil's phrase here so exactly replicates Rhianus' that it could be considered a direct imitation, especially given the other Virgilian convergences with Rhianus we have already observed (Eclogues IV 63, 
Georgics IV 560-561), unless we are just seeing variations on the standard phrasing of a standard idea. The same language and idea do indeed recur in Hellenistic epigrams, by

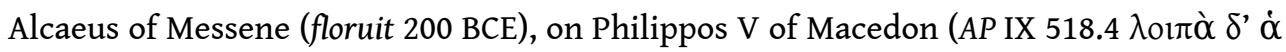

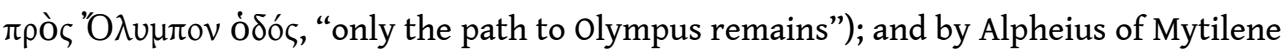

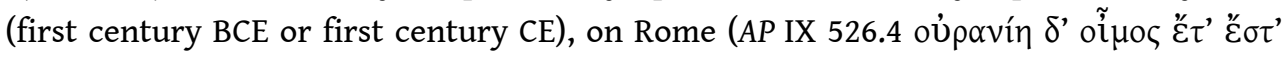

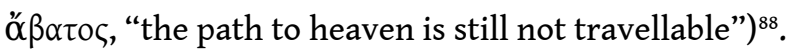

It is far from clear that the expression "attempting / travelling a path to Olympus" is always literally meant. It can also be understood as a figurative expression for "aspiring to become (quasi-)immortal through one's greatness," without any suggestion that the person concerned ever thought of literally ascending towards Olympus ${ }^{89}$. Something very like a literal ascent to heaven is found in connection with that Gottmensch par excellence, Alexander the Great, in recension L of the Alexander Romance, where Alexander contrives a way to fly to heaven by yoking together two outsize birds (Pseudo-Callisthenes, Historia Alexandri Magni II 41.9-13) ${ }^{90}$. This is not explicitly described as an attempted ascent to Olympus, but is juxtaposed in the narrative with

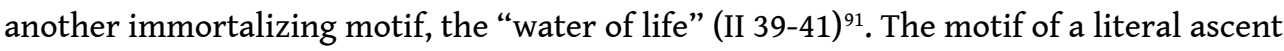
to heaven is found in Mesopotamia from an early date: a Sumerian king-list features the entry, "Etana, the shepherd, the one who went to heaven, who put all countries in order, was king; he reigned 1,500 years"; and Etana's flight to heaven on the back of an eagle was the subject of a major poem in Akkadian, Etana, whose tradition reaches back into the third millennium $\mathrm{BCE}^{92}$. This poem, like Gilgamesh, is concerned with a form of the quest for immortality ${ }^{93}$. It may have been known to archaic Greeks: there are striking apparent reflections of it in Archilochus' "Lykambes epode" (frr. 172-181 West) and the Aesopic fable of "The Eagle and the Dung-beetle" (Aesopica 3 Perry: compare already Semonides fr. 13 West $)^{94}$. The Aesopic fable is explicitly a model for Trygaios' ascent on the dung-beetle (Peace 129-130). Greek myths famously feature (ill-fated) literal ascents to heaven: Bellerophon rides Pegasos to heaven (Pindar, Isthmian VII 43-48; Euripides, Bellerophon, etc.) and Otos and Ephialtes pile Mt Ossa on Mt Pelion in order to reach Olympus (Odyssey XI 313-316, etc.). Polyaenus preserves an intriguing story pertaining to the non-mythical domain, which can unfortunately be neither sourced nor dated: a Thracian general Kosingas played on his troops' naivety by having wooden ladders fitted together so that he could ascend to Olympus to inform Hera of his troops' disobedience (Stratagems in War VII 22). Trygaios attempts a similar expedient of climbing ladders to heaven, before hitting on the plan with the dungbeetle (Peace 69-71) ${ }^{95}$. The association of a literal ascent to heaven with Gottmenschentum recurs in the first appearance of Sokrates in Clouds: Sokrates, while he "treads the air" $(\dot{\alpha} \varepsilon \rho \circ \beta \alpha \tau \tilde{\omega})$ in a suspended basket, addresses Strepsiades as if he himself were not

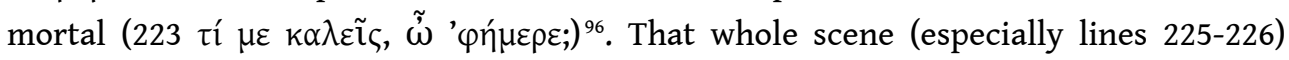
stages an early version of the motif of the philosopher's metaphorical conquest of the gods' heavenly realm (compare Lucretius I 62-79; Pseudo-Aristotle, On the Cosmos 391a8-12) ${ }^{97}$. There is probably also a metatheatrical play here on the conventional use, in both tragedy and comedy, of the mēchane for the gods, here appropriated for Sokrates ${ }^{98}$. While absurd "literalizations" of figurative notions are the stock-in-trade of Old Comedy", the notion of "making one's way to heaven", like the notions of "thundering" and "marrying a goddess" that were considered above (§§6-8), was both standardly attached to Gottmensch-figures and was apparently capable of being literally meant. 


\section{Gottmenschentum in Aristophanes are typically interwoven with paratragic,} metapoetical, and/or metatheatrical elements ${ }^{100}$. On the one hand, the coarse-grained immortalizing themes in Knights, Peace, and Birds look also to tragic treatments of those themes: rejuvenation by boiling (compare Euripides, Peliades, testimonia iii a-c Kannicht); flying to the gods in Olympus (compare Euripides' Bellerophon, frr. 306-308 Kannicht); marriage to a goddess (compare Euripides, Phaethon lines 227-244, where we

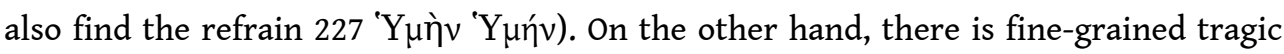
intertextuality, paratragedy, and metatheatre in each of the Aristophanic passages discussed above.

First, Birds 1706-1720. It was argued above (\$§2-14) that the epiphanic re-entry of the apotheosized Peisetairos in the closing scene of Birds evoked the forms and language of the real, lived, experience of epiphany. However, the speech of the Messenger (1706-1719) not only evokes the speech of a hierokeryx, announcing the imminent arrival of a deity or Gottmensch; it also recalls equivalent scenes of tragedy, notably the speech of the Messenger in Aeschylus' Agamemnon (518-532), preparing the Argives for the triumphal return of Agamemnon ${ }^{101}$. Similarly, Peisetairos' entrance by chariot at Birds 1720(ff.) not only looks to real-life Gottmenschen, as argued above, but also to chariot entrances in tragedy, such as, for instance, Agamemnon's triumphal entry at Aeschylus' Agamemnon 810(ff.) ${ }^{102}$. The evocation of real practices jostles with paratragedy.

Second, Knights 147-150. The language used by "Demosthenes" / "Servant 1" at the first appearance of the Sausage-Seller as a "saviour" in Knights was argued above $(\$ \S 17,20)$ to evoke the themes of "advent" and "presence" of a deity or Gottmensch in epiphany.

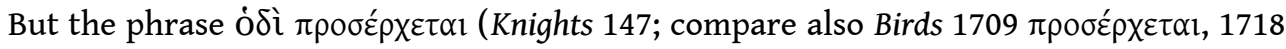

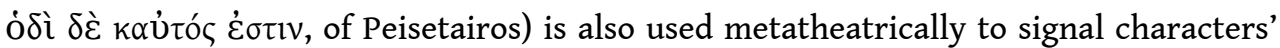

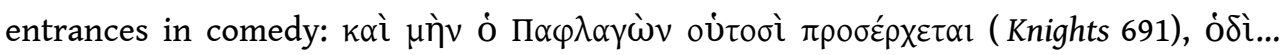

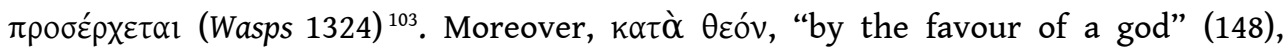
suggests not just the theme of the "heaven-sent" saviour-figure, but also a tongue-incheek allusion to the convenient dramatic convention whereby a character enters the

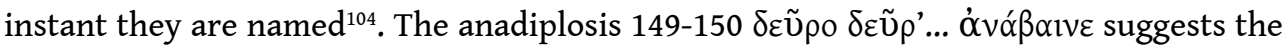
"come hither, hither" formula found in cletic addresses to divinities (or human saviours: Sophocles, Oedipus Tyrannus 46-47 ' $\theta^{\prime}$ '..., ' $1 \theta$ '...); but the use of an imperative of

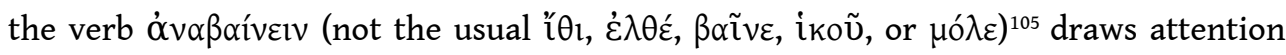


metatheatrically to the fact that an actor here is being asked to "come onto" the stage, for which, as the scholiast points out, $\alpha$ $v \alpha \beta \alpha$ ívelv was the technical term ${ }^{106}$.

Third, Knights 1326-1328. The re-entry of the rejuvenated, apparently apotheosized, DEMOS was argued to evoke a divine epiphany. The motif of the populace "seeing" the

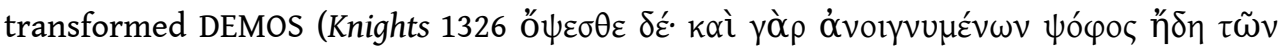
$\pi \rho 0 \pi u \lambda \alpha i ́ \omega v$, "you shall see for yourselves: for there is already the noise of the Propylaea being opened") is appropriate to an epiphany ${ }^{107}$. We may compare the ithyphallic hymn to Demetrios, $18 \sigma \varepsilon \grave{\varepsilon} \delta \grave{\varepsilon} \pi \alpha \rho o ́ v \theta$ ' ó $\rho \tilde{\omega} \mu \varepsilon v$, "we see you present to us." But the same language was used in tragedy and comedy to signal that something was about to be shown to the audience, often by means of the ekkyklemma ${ }^{108}$. A good tragic

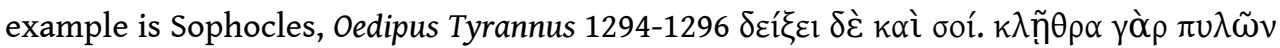

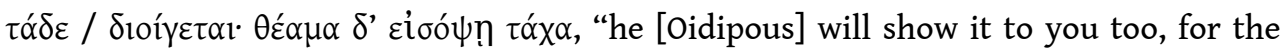
bars of the gates are being opened, and you shall soon see the sight yourself."

Fourth, Peace 913-921. This passage, in which Trygaios is declared a "saviour", is shot

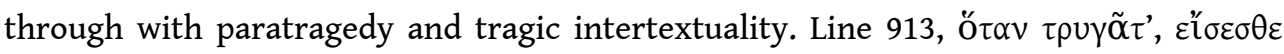

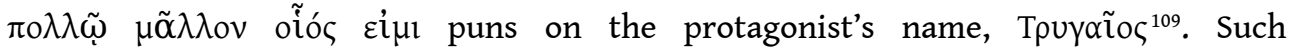
etymological play on protagonist's name, hinting at their essential characteristic, was a typical feature of tragedy: note Sophocles, Ajax 430-431 (Aias and aíã)); Oedipus

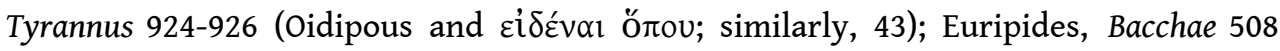

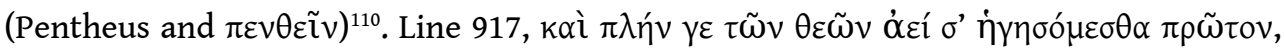
may be allusively intertextual with Sophocles, Oedipus Tyrannus 31-34 (discussed above,

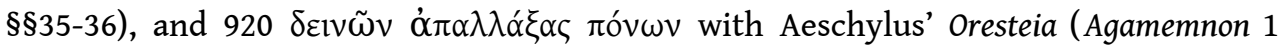

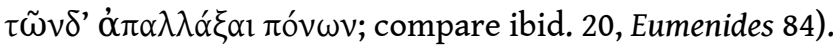

Throughout all these passages we should recognize the co-presence of elements of paratragedy or metatheatre with elements of parody of religious practices and of Gottmenschentum. The audience is pulled in two directions simultaneously: towards the real (practised) and the unreal (the theatrical, the world of poetic precedent) ${ }^{111}$. The paratragedy and metatheatre effect a distancing from and a deflation of the real-life practices associated with Gottmenschentum at the same time as the language and conceits of the comedy "zoom" the audience to those real-life practices. This conflation of metapoetry and the real-life aggrandizement of the Gottmensch is itself a phenomenon of (literary) historical significance: it is transmitted to the poetry of both Alexandria (Callimachus, Aetia fr. 1.20 Harder: see above, §8) and Rome (Virgil, Georgics III 1-48, IV 559-566). We should not assume a zero-sum relationship between paratragedy and metatheatre, on the one hand, and parody of real religious practices, on the other. Recognition of the one does not come at the expense of the other; rather, in this poetic genre, both feed off each other. In any case, we should be wary of constructing a simple opposition between "references to cult" and "references to tragedy", for the twin reasons that tragedy may itself complexly reflect real religious practices and that real life was capable of imitating tragedy (see below, $\S 556,58,61$, for both points). 


\section{Comic parody of the sōtēr- / Gottmensch-figure}

50 The sōtèr- / Gottmensch-figure is important in three of Aristophanes' extant plays. In a recent discussion of religion in comedy, Revermann argued old Comedy to be disinterested in hero cult, noting that:

Comedy is not eschatological: "last things" are not its concern. What matters is the

"(right) here and (right) now" (and the fun!) $)^{112}$.

51 Similarly, Sophoclean tragedy has been argued to be unconcerned with hero cult, on the grounds that intimations of hero cult for Aias in Ajax, Herakles in Trachiniae, or Oidipous in Oedipus at Colonus would be incompatible with the desired "tragic effect." But myriad perspectives are possible on hero cult. There is a tragic perspective that is fully compatible with the effect at which Sophocles was aiming ${ }^{113}$. So, too, there is a comic perspective. In Old Comedy, hero cult (in a broad sense: specifically, cult of the sōtèr or the Gottmensch) takes on a particular comic inflection, salient aspects of which may be adumbrated as follows.

52 First, it is the Sausage-Seller's superabundance of meanness (kakia) that makes him into a sōtēr-figure (Knights 128-144, 180-181, 185-193), perverting the popular belief, cited by Aristotle, according to which men became gods owing to a superabundance of aretē (Nicomachean Ethics 1145a22-24) ${ }^{114}$. This accords with comedy's generic concern to represent men as worse than they are (Aristotle, Poetics 1448a17-18).

53 Second, the comic perspective on the cult of sōter is brazenly hedonistic. Trygaios conceives of himself, and the farmers acclaim him, as sōtêr for the sensual pleasures he confers on them (Peace 866-867, 913-921) - a characteristically comic distortion of what being "saved" entails. Likewise, Trygaios' status as Gottmensch is measured in the sensual pleasures that he will himself enjoy, and the same goes for the rejuvenated, apotheosized DEMOS in Knights ${ }^{115}$.

54 Third, the comic sōtêr may be cynical and self-interested. Anticipating Napoleon in Orwell's Animal Farm, Peisetairos obtains BASILEIA for himself by undertaking to secure it for the birds. The Sausage-Seller, by contrast, surprises us with his renunciation of self-interest.

55 Fourth, the routes towards Gottmenschentum in comedy are fantastic, ridiculous, and bathetic: Peisetairos is turned into a bird; Trygaios rides an outsize dung-beetle; DEMOS is "boiled down" by the Sausage-Seller, an achievement which makes us think not just of Medeia and Aëson in mythology, but also, with a miraculous transformation of the quotidian, of the Sausage-Seller's own particular expertise as a peddler of cooked meat ${ }^{116}$.

56 Heroization was a fact of fifth-century Greek life with which the three major fifthcentury poetic genres - epinician, tragedy, and comedy - engaged in distinctive ways. Pindaric epinician and Sophoclean tragedy are interested, although in different ways, in the status and the fortunes of, respectively, the athletic victor and the tragic hero, both in their lifetime and after their death ${ }^{117}$. The orientation of comedy is this-worldly;

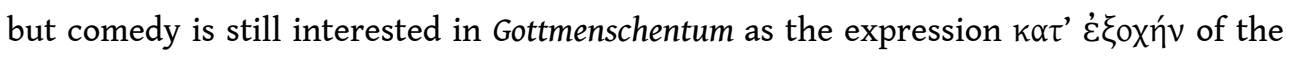
comic hero's triumph ${ }^{118}$. This goes for the Sausage-Seller in Knights, Trygaios in Peace, and Peisetairos in Birds ${ }^{119}$. Comedy appears, moreover, to have a distinctive interest, not shared with epinician or tragedy, in satirizing the attitude of the populace (via choruses of knights, farmers, and gullible birds) towards Gottmensch-figures, and in 
satirizing the means by which an individual who stops at nothing could attain to the status of Gottmenschentum.

57 Heroization and Gottmenschentum were certainly ripe for comic treatment. They were inherently exposed to criticism or ridicule, of an ad hominem or a principled kind, aimed either at the person heroized or the people heroizing or both ${ }^{120}$. This is obvious in Lucian's satirical treatment of Alexandros of Abonutichus and Peregrinos Proteus in the second century CE (Alexander the False Prophet, On the Death of Peregrinus) ${ }^{121}$. But it is apparent already in Herodotus' scandalized account of Peisistratos' hoodwinking of the

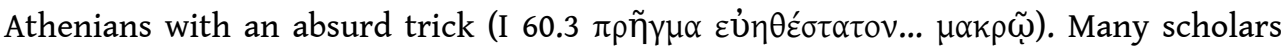
have seen the Peisistratos of the Phye-as-Athena episode as an ironic model for the nearly homonymous Peisetairos (if the name is thus correctly restored) of Aristophanes' Birds ${ }^{122}$. Further, Ktesippos in Plato's Lysis (205d1-2) ridicules Hippothales for peddling "old wives' tales" about Lysis' ancestor being a son of Zeus: Amphitheos in Aristophanes' Acharnians is ridiculous in a very similar way, when he argues himself to be a descendant of Demeter (47-51). Much fifth- and fourth-century Gottmenschentum appears to be comedy already made. The fourth-century BCE physician Menekrates, who impersonated Zeus, was unsurprisingly a butt of contemporary comedy (Ephippus, The Peltast, fr. 17 Kassel-Austin; Alexis, Minos, fr. 156 Kassel-Austin). He was viewed by sober writers in antiquity as a megalomaniac madman (Athenaeus VII 289a-f; Aelian, Various History XII 51) ${ }^{123}$. But megalomaniacs are also the lifeblood of comedy, a genre where the crazy, zany, and hair-brained could triumph and be celebrated. The views of the social-intellectual elite and of the masses towards Gottmenschentum doubtless diverged throughout antiquity ${ }^{124}$. Comedy was the perfect place to play the cynicismscepticism of the one off the enthusiasm-gullibility of the other.

Another reason why Gottmenschentum naturally leant itself to representation on the comic stage is that there was often a pronounced theatrical or play-acting element to real-life treatments of the Gottmensch ${ }^{125}$. The theatricality in the staging of the reception of the Hellenistic king and of royal appearances has been well studied ${ }^{126}$. Klearchos is said to have worn the tragic buskin, kothornos, "like the kings of tragedy" (Justin XVI 5.10) ${ }^{127}$. Philippos II had a statue of himself as a thirteenth Olympian god paraded in the theatre of Aegae (Diod. XVI 92.5, XVI 95.1) 128 . Demetrios appears to have staged his entrance into Athens as "Dionysos" in the theatre at the Dionysia of 295 BCE (Plutarch, Demetrius 34.4) ${ }^{129}$. The ithyphallic hymn, through sustained intertextuality with Sophocles' Oedipus Tyrannus (see above, \$36), assimilated the Athenians' relationship with Demetrios to the Thebans' relationship to Oidipous on the tragic stage. Marcus Antonius, like Demetrios, imitated the dress of Dionysos (Seneca, Suasoriae I 6) ${ }^{130}$. Lucian presents Alexandros of Abonutichus' entry into Abonutichus as a tragic drama (Alexander 12) ${ }^{131}$. Stunts like simulations of thunder (recorded for the mythical Salmoneus) or attempts to ascend to Olympus (attributed to the Thracian general Kosingas) are intrinsically stagey. All these postdate old Comedy; but Peisistratos' return to Athens in the mid-sixth century, with Phye masquerading as Athena, comfortably precedes it; this has been attractively explained by Connor as a real-life "drama", in which the Athenians showed themselves complaisant ${ }^{132}$. Comedy, we may take it, was adroit at adopting such dramas of Gottmenschentum, owning them to be already the stuff of the theatre, but in a deflating, comic, rather than an elevating, tragic, kind of way. 


\section{Comedy and the early history of the saviour / Gottmensch}

59 The Aristophanic picture needs to be integrated into the history of the Gottmensch and the cult of the saviour. It needs in particular to be related to Duris' statement, as relayed by Plutarch, that Lysandros "was the first of the Greeks... to whom the cities set up altars as a god and made sacrifices; and paeans were sung to him first" (Duris BNJ 76 F71, in Plutarch, Lysander 18.5) ${ }^{133}$. This Samian cult of Lysandros dates to 404 BCE, ten years after Birds and twenty after Knights.

It might be supposed that Aristophanes' depiction of Gottmenschentum and saviour-cult does not take its cue from any real-life practices, but is just the stuff of mythology and comic fantasy ${ }^{134}$. Or perhaps it was a vein of humour in Old Comedy to show characters on stage acting out ideas about Gottmensch- or saviour-figures that circulated only as ideas before $404 \mathrm{BCE}$, when for the first time the Samians put them into practice.

61 However, there are difficulties with such views. A first objection is that Gottmenschentum is a theme of so much fifth-century Athenian dramatic poetry. Gottmenschentum features in three extant Aristophanic plays (not, as sometimes supposed, in Birds alone) ${ }^{135}$. Its representation in the lost plays of old Comedy can only be guessed $a^{136}$. In tragedy, too, Gottmenschentum is often a significant theme: we have had occasion to refer repeatedly to certain passages of, in particular, Aeschylus' Agamemnon, Sophocles' Oedipus Tyrannus, and the Pseudo-Euripidean Rhesus. Secondly, there is depth, as well as breadth, to the exploration of Gottmenschentum in the three comedies of Aristophanes: Aristophanes is able to exploit an extensive and welldeveloped terminology, as well as very concrete forms of treatment of the saviour- / Gottmensch-figure. It is hard to imagine that the elements of Gottmenschentum would have been available to be exploited in precisely this way (so frequently, so detailedly, and so presciently of subsequent cult practices) without their having any correlate in contemporary practice. Thirdly, it seems impossible to do justice to the comic texts' treatment of the theme without assuming some engagement with real practices: this kind of comic parody (not least, the tension between metatheatrical reference and cultic reference) requires a corresponding reality to bite on. Consequently, it is worth considering what scope Duris' statement about Lysandros' cult leaves us to postulate a correlate in contemporary reality for Aristophanes' depiction of civic saviours / Gottmenschen.

Duris does not actually say that Lysandros was the first of the Greeks to whom anyone made sacrifices, dedicated altars, and sang paeans, but the first to whom "the cities" did so ${ }^{137}$. Duris' wording leaves open the possibility that individuals or even collectives may previously have done any of these things on their own initiative, without it having been voted through by the assembly or equivalent. If our poetic texts are anything to go by, then the performance of religious acts (the erection of altars, the making of sacrifices, etc.) was an appropriate or expected response by individuals in Greco-Roman antiquity when they took themselves to be face to face with a deity or Gottmensch. In the "Homeric" Hymn to Aphrodite, Anchises envisages doing this for the disguised Aphrodite (100-102: altar and sacrifices) ${ }^{138}$. So does Danaos, along with his daughters, for the Argives, declared to be their "saviours", in Aeschylus' Suppliant Women (980-982: prayers, sacrifices, and libations). So too does Tityrus for the "young man", sc. Octavian, in Virgil's first Eclogue (7-8: altar and sacrifices) ${ }^{139}$. Horace envisages a similar 
state of affairs for Augustus in his Epistle to Augustus (Epistles II 1.15-17: altars and sacrifices $)^{140}$. The fact that this theme recurs in poetic but not historiographical texts need not imply that the theme has no purchase in reality; poetic texts are more interested than historiographical ones in exploring the religious responses of individuals to events (historical or fictitious). Non-poetic texts offer confirmation of the general point, at least, that private individuals might institute cults on their own initiative, operating outside the auspices of the polis (Plato, Laws 909d7-910e3; Theophrastus, Characters XVI 4) ${ }^{141}$.

But did any perceived saviour- / Gottmensch-figure of the fifth century BCE actually receive sacrifices, altars, etc., from persons acting in a non-civic capacity? Plutarch attests this for Dion at Syracuse in 357/6 BCE, half a century after Lysandros' civic cult on Samos, reporting that "the Syracusans", evidently in a non-civic capacity, offered him animal sacrifices, first-fruits, and supplications-prayers (Dio 29.2). We are not obliged to accept this testimony; Plutarch is not a contemporary source and his account may be coloured by the way Hellenistic and Roman Gottmenschen were treated. But why suppose that this kind of non-civic treatment of a saviour / Gottmensch only became possible after the Samians had instituted a civic cult for Lysandros? Nothing suggests that a civic cult must pave the way for non-civic popular veneration of a Gottmensch. If anything, the converse progression is more logical.

Only one - discredited - text records a populace in a non-civic capacity making sacrifices, establishing altars, etc., to a perceived saviour- / Gottmensch-figure prior to Lysandros' cult on Samos in 404 BCE. Justin (Trogus) states that when Alkibiades entered the Piraeus in $408 \mathrm{BCE}$, the Athenians "heaped upon him not only all the honours for men, but also for gods" (V 4.6-18). Justin's (Trogus') expression diuinis... honoribus should imply, among other things, altars and sacrifices ${ }^{142}$. Justin (Trogus) is, again, not a contemporary source. It is unclear how much of this may go back to earlier Greek sources, such as the fourth-century Ephorus, and how much may be Justin's (Trogus') own elaboration ${ }^{143}$. Likewise unclear is whether Justin's (Trogus') Romanization of the account can be regarded as an essentially harmless linguistic veneer or as amounting to a more serious distortion of the facts themselves ${ }^{144}$. Habicht considered Justin's (Trogus') report refuted by Demosthenes' statement that Conon in $394 \mathrm{BCE}$ was the first Athenian since the tyrannicides to receive a civic statue (Against Leptines 68-71), implying that a statue, not "divine honours", was still the highest conceivable civic award at that time ${ }^{145}$. The supposed refutation fails, however, because Demosthenes is speaking of civic awards, while Justin is describing (and we are interested in) non-civic responses from the Athenian multitude to Alkibiades ${ }^{146}$. Habicht further objects that other sources describe Alkibiades' reception in AthensPiraeus in 408 BCE without mentioning anything like "divine honours"147. Nepos mentions Alkibiades receiving (on the most plausible reading of the text) "laurel crowns and tainiai", like an Olympic victor (Alcibiades 6.3) ${ }^{148}$. Nepos is emphatic that Alkibiades' treatment was unprecedented in this respect, but this claim is exposed as erroneous by Thucydides' description of Brasidas at Scione in 423 BCE being showered with tainiai "like an athlete" (IV 121.1) ${ }^{149}$. Nepos does not offer a dependable account to oppose to Justin's (Trogus'), and he cannot be regarded as knowledgeable of the noncivic honours that a fifth-century saviour / Gottmensch could receive. The other extant narratives have even less to say about how the Athenians received the returning Alkibiades ${ }^{150}$. It must be recognized that historiographical texts are not uniformly 
interested in such questions ${ }^{151}$. Xenophon and Plutarch are more interested in the vicissitudes in Alkibiades' career and in his self-vindication before the Athenians.

The point at issue should not be whether we can rely on or can refute Justin (Trogus), but how fragile our information about early saviour- or ruler-cult is. Scholarship now mostly accepts Lysandros' cult at Samos as a watershed in the history of ruler-cult. Yet our knowledge of it depends on a single much later historian (Plutarch) quoting another non-contemporary historian (Duris). This notice might easily not have come down to us. Xenophon says nothing about the Samians' civic cult for Lysandros, although he narrates Lysandros' intervention in Samos (Hellenica II 3.6-8) ${ }^{152}$. Scholarship was long divided over whether to accept Duris' claims or not ${ }^{153}$. What needs to be emphasized is that our understanding of the early history of ruler-cult is liable to fall out quite differently according to whether we happen to possess certain isolated notices - in our literary sources - and on whether we decide to accept their claims ${ }^{154}$. Epigraphic confirmation, seen as clinching matters with Lysandros' Samian cult, is not to be looked for with the non-civic attentions received by fifth-century Gottmenschen.

Duris' statement about Lysandros still permits us to conceive of the early history of saviour-cult as a graduated process. Before Lysandros, it may have been possible for saviour- / Gottmensch-figures to receive divine honours from the people in an unofficial, non-civic, capacity. It may even have been possible before Lysandros for Gottmenschfigures to receive heroic (as opposed to divine) honours by civic decree ${ }^{155}$. Lysandros will have been the first to have received divine, and not merely heroic, honours by civic decree (and, Duris implies, in more than one city-state). Duris therefore can have recognized Lysandros as a forerunner of the Gottmenschen of his own lifetime (Antigonos Monophthalmos, Demetrios Poliorketes). Of course, the step that was taken with Lysandros on Samos in 404 BCE was a transformational development; we may even take the view that saviour- / ruler-cult only really becomes a truly historically significant phenomenon from then on. But it will not be the case that particular political circumstances, born of the closing years of the Peloponnesian war and, especially, of the later fourth century BCE (viz., the city-state's dependence on a powerful outsider for its survival and its need to reciprocate with civic rewards proportionate to the service rendered by its "saviour") led to the creation ex nihilo of new religious categories and practices (the saviour- / Gottmensch-figure; saviour- / ruler-cult). Rather, we may see the changed political situation as leading to the politicization and the adoption in civic religion (and consequent transformation) of what had previously been a popular religious phenomenon of informal character. In this putative process, a popular phenomenon, at which the political elite may be assumed to have looked distinctly askance while it had the luxury of so doing, will have gradually entered the political mainstream of various poleis. (Such a development is perhaps the easier to conceive in the age of Trump and Brexit.)

In the absence of (reliable) historiographical or epigraphic testimony, it is all the more pressing how we decide to appraise the fifth-century BCE poetic texts, as offering our only contemporary window onto fifth-century Gottmenschentum. Aristophanes' comedies are a still undervalued source here ${ }^{156}$. They are not the only one, however: I should like to draw attention here (again) to Pindar's second Pythian, lines 18-20, as strongly suggesting that in the early $470 \mathrm{~s}$ BCE Hieron was celebrated in religious choral songs as saviour of the Epizephyrian Locrians, anticipating Lysandros on Samos in at least that respect ${ }^{157}$. The upshot of the present discussion is that there is a murky pre- 
history of saviour-cult before Lysandros that has a legitimate claim on our attention, and whose reconstruction requires us to take appropriate account of poetic texts and to consider possible non-civic treatments, in addition to the civic cults, that were received by Classical and Archaic sōter- / Gottmensch-figures. The essential point is that living men may have become gods or heroes not merely in the popular imagination and in poetic fantasy, but also in popular religious practice, well before they did so in official civic religion.

\section{BIBLIOGRAPHY}

ALEXANDRI-TzAHou 1986: O. Alexandri-Tzahou, s.v. 'Demos', LIMC iii.1.375-382, 1986.

ANDERSON 2015: R. Anderson, «New Gods», in EIDINOW, KINDT 2015, 309-323.

BAKOLA 2010: E. Bakola, Cratinus and the Art of Comedy, Oxford 2010.

BARTOL 2016: K. Bartol, «The Song for Demetrios Poliorcetes (CA 173) and Generic

Experimentations in the Early Hellenistic Period», Paideia 71 (2016), 501-518.

BONNER 1943: C. Bonner, «Sovereignty and the Ambitious Hero», American Journal of Philology 64 (1943), 208-210.

BowIE 1993: A. M. Bowie, Aristophanes: Myth, Ritual, and Comedy, Cambridge 1993.

BRINK 1982: C. O. Brink, Horace on Poetry, vol. 3 Epistles Book II: The Letters to Augustus and Florus, Cambridge 1982.

BURSTEIN 1974: S. M. Burstein, «Sceptre or Thunderbolt: Plutarch Moralia 338», California Studies in Classical Antiquity 7 (1974), 89-92.

Cerfaux, Tondriau 1957: L. Cerfaux, J. Tondriau, Un concurrent du Christianisme. Le culte des souverains dans la civilisation gréco-romaine, Tournai 1957.

CHANIOTIS 1997: A. Chaniotis, «Theatricality Beyond the Theatre: Staging Public Life in the Hellenistic World», in B. Le Guen (ed.), De la scène aux gradins: Théâtre et représentations dramatiques après Alexandre le Grand, Toulouse 1997, 219-259.

CHANIOTIS 2003: A. Chaniotis, «The Divinity of Hellenistic Rulers», in A. Erskine (ed.), A Companion to the Hellenistic World, Malden (MA) 2003, 431-446.

CHAniotis 2011: A. Chaniotis, «The Ithyphallic Hymn for Demetrios Poliorketes and Hellenistic Religious Mentality», in P. P. Iossif, A. S. Chankowski, C. C. Lorber (eds), More than Men, Less than Gods: Studies on Royal Cult and Imperial Worship. Proceedings of the International Colloquium Organized by the Belgian School at Athens (November 1-2, 2007), Leuven - Paris 2011, 157-195.

Cingano 1995: E. Cingano, «Pitica I», in B. Gentili, E. Cingano, P. Giannini, P. A. Bernardini (eds.), Pindaro: Le Pitiche, Milano 1995, 9-23.

ConNoR 1987: W. R. Connor, «Tribes, Festival, and Processions: Civic Ceremonial and Political Manipulation in Archaic Greece», Journal of Hellenic Studies 107 (1987), 40-50. 
CURRIE 2002: B. G. F. Currie, «Euthymos of Locri: A Case Study in Heroization in the Classical Period», Journal of Hellenic Studies 122 (2002), 24-44.

CURRIE 2005: B. G. F. Currie, Pindar and the Cult of Heroes, Oxford 2005.

CURRIE 2012: B. G. F. Currie, «Sophocles and Hero Cult», in K. Ormand (ed.), A Companion to Sophocles, Malden (MA) 2012, 331-348.

CURRIE 2016: B. G. F. Currie, Homer's Allusive Art, Oxford 2016.

CURRIE (forthcoming): B. G. F. Currie, «Etana in Greece», in A. Kelly, C. Metcalf (eds), Gods and Mortals in Early Greek and Near Eastern Mythology, Cambridge forthcoming.

DEVELIN 1994: R. Develin, «Introduction», in J. C. Yardly, R. Develin, Justin: Epitome of the Philippic History of Trogus, Atlanta 1994.

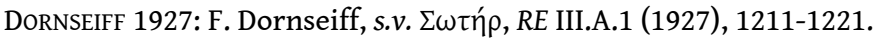

DOVER 1968: K. J. Dover, Aristophanes Clouds, Oxford 1968.

DUNBAR 1995: N. Dunbar, Aristophanes Birds, Oxford 1995.

EIDINOW, KINDT 2015: E. Eidinow, J. Kindt (eds), The Oxford Handbook of Ancient Greek Religion, Oxford 2015.

FARAONE 1997: C. A. Faraone, «Salvation and Female Heroics in the Parodos of Aristophanes' Lysistrata», Journal of Hellenic Studies 117 (1997), 38-59.

FEDELI 1983: P. Fedeli, Catullus' Carmen 61, Amsterdam 1983.

FINGLASS 2018: P. J. Finglass, Sophocles Oedipus the King. Edited with Introduction, Translation, and Commentary, Cambridge 2018.

FLOWER 1988: M. A. Flower, «Agesilaus of Sparta and the Origins of the Ruler Cult», Classical Quaterly 38 (1988), 123-134.

FRIES 2014: A. Fries, Pseudo-Euripides, Rhesus, edited with an Introduction and Commentary, Berlin - Boston 2014.

GARLAND 1992: R. Garland, Introducing New Gods: The Politics of Athenian Religion, Ithaca (NY) 1992. GLASSNER 2004: J.-J. Glassner, Mesopotamian Chronicles (ed. or. Paris, 1993), Engl. transl., LeidenBoston 2004.

GLOWACKI 2003: K. Glowacki, «A Personification of Demos on a New Attic Document Relief», Hesperia 72 (2003), 447-466.

GRAF 2005: F. Graf, s.v. 'kataibates', BNP 7 (2005), 30.

HABICHT 2017: C. Habicht, Divine Honors for Mortal Men in Greek Cities: The Early Cases (ed. or. Munich 1970), Engl. transl., Ann Arbor 2017.

HALLOF 2000: K. Hallof (ed.), Inscriptiones Graecae XII.vi.1, Berlin-New York 2000.

HARDIE 1986: P. R. Hardie, Virgil's Aeneid: Cosmos and Imperium, Oxford 1986.

HARDIE 1998: P. R. Hardie, Virgil = Greece \& Rome New Surveys in the Classics No. 28, Cambridge 1998.

HAUl 2000: M. Haul, Das Etana-Epos. Ein Mythos von der Himmelfahrt des Königs von Kiš, Göttingen 2000. 
HENKELMAN 2006: W. F. M. Henkelman, «The Birth of Gilgameš (Ael. NA XII.21). A Case-Study in Literary Receptivity», in R. Rollinger, B. Truschnegg (eds), Altertum und Mittelmeerraum: die antike Welt diesseits und jenseits der Levante: Festschrift für Peter W. Haider zum 60. Geburtstag, Stuttgart 2006, 807-856.

Holt 2003: F. L. Holt, Alexander the Great and the Mystery of the Elephant Medallions, Berkeley - Los Angeles - London 2003.

HOPKINSON 1988: N. Hopkinson, A Hellenistic Anthology, Cambridge 1988.

HORNBLOWER 2001: S. Hornblower, «The Religious Dimension to the Peloponnesian War, or, what Thucydides Does not Tell Us», in S. Hornblower, Thucydidean Themes, Oxford 2011, 25-53 (first published in Harvard Studies in Classical Philology 94 (1992), 169-197).

HORNBLOWER 1996: S. Hornblower, A Commentary on Thucydides Volume II: Books iv-v.24, Oxford 1996. HORNBLOWER 2011: S. Hornblower, The Greek World 479-323 BC, $4^{\text {th }}$ edn., London - New York 2011. HORNBLOWER 2008: S. Hornblower, A Commentary on Thucydides Volume III: Books 5.25-8.109, Oxford 2008.

HUNTER 2004: R. L. Hunter, Plato's Symposium, Oxford 2004.

JEBB 1893: R. C. Jebb, Sophocles: The Plays and Fragments. Part 1: The Oedipus Tyrannus, $3^{\text {rd }}$ edn., Cambridge 1893.

JIM (forthcoming): T. S. F. Jim, Saviour Gods and Soteria in Ancient Greece (provisional title), Oxford forthcoming.

JONES 2010: C. P. Jones, New Heroes in Antiquity: From Achilles to Antinoos, Cambridge (MA) - London 2010.

KanAVou 2011: N. Kanavou, Aristophanes' Comedy of Names: A Study of Speaking Names in Aristophanes, Berlin - New York 2011.

KavoulaKi 1999: A. Kavoulaki, «Processional Performance and the Democratic Polis», in S. Goldhill, R. Osborne (eds), Performance Culture and Athenian Democracy, Cambridge 1999, 293-320.

KLEINKNECHT 1937a: H. Kleinknecht, Die Gebetsparodie in der Antike, Stuttgart - Berlin 1937.

KLEINKNECHT 1937b: H. Kleinknecht, «Zur Parodie des Gottmenschentums bei Aristophanes», Archiv für Religion Wissenschaft 34 (1937), 294-313.

KLEINKNECHT 1939: H. Kleinknecht, «Die Epiphanie des Demos in Aristophanes' Rittern», Hermes 77 (1939), 58-65 [Repr. with "Korrekturnachtrag" in H.-J. Newiger (ed.), Aristophanes und die Alte Komödie, Darmstadt 1975, 144-154].

KRON 1979: U. Kron, «Demos, Pnyx, und Nymphenhügel: Zu Demos-Darstellungen und zum ältesten Kultort des Demos in Athen», Mitteilungen des Deutschen Archäologischen Instituts, Athenische Abteilung 94 (1979), 49-75.

LANDFESTER 1967: M. Landfester, Die Ritter des Aristophanes, Amsterdam 1967.

LANE Fox 1973: R. J. Lane Fox, Alexander the Great, London 1973.

LANE FOX 1996: R. J. Lane Fox, «Text and Image: Alexander the Great, Coins and Elephants», Bulletin of the Institute of Classical Studies 41 (1996), 87-108.

LEVENE 1997: D. S. Levene, «God and Man in the Classical Latin Panegyric», Proceedings of the Cambridge Philological Society 43 (1997), 66-103. 
MORGAN 2015: K. A. Morgan, Pindar and the Construction of Syracusan Monarchy in the Fifth Century B.C., Oxford 2015.

MYNors 1990: R. A. B. Mynors, Virgil Georgics. Edited with a Commentary, Oxford 1990.

NisBet, HubBARD 1970: R. G. M. Nisbet, M. A. Hubbard, A Commentary on Horace Odes Book I, Oxford 1970.

NocK 1928: A. D. Nock, «Notes on Ruler-Cult I-IV», Journal for Hellenic Studies 48 (1928), 21-43 (reprinted in Nock 1972: i.134-159).

Nock 1951: A. D. Nock, «Soter and Euergetes», in S. L. Johnson (ed.), The Joy of Study: Papers on New Testament and Related Subjects Presented to Honor Frederick Clifton Grant, New York 1951, 127-148 (reprinted in NocK 1972: ii.720-735).

Nock 1972: A. D. Nock (ed. Z. Stewart), Essays on Religion and the Ancient World, Oxford 1972.

O'SUlLivan 2008a: L. O'Sullivan, «Marrying Athena: A Note on Clement Protrepticus 4.54», Classical Journal 103 (2008), 295-300.

O'sulLIVAN 2008b: L. O'Sullivan, «Le Roi Soleil: Demetrius Poliorcetes and the Dawn of the SunKing», Antichthon 42 (2008), 78-99.

OBER 1989: J. Ober, Mass and Elite in Democratic Athens: Rhetoric, Ideology, and the Power of the People, Princeton 1989.

OLSON 1992: D. S. Olson, «Names and Naming in Aristophanic Comedy», CQ 42, 2 (1992), 304-319.

OLSON 1998: D. S. Olson, Aristophanes Peace, Oxford 1998.

PARKER 2005: R. T. C. Parker, «Law and Religion», in M. Gagarin, D. Cohen (eds), The Cambridge Companion to Ancient Greek Law, Cambridge 2005, 61-81.

PARKER 2011: R. T. C. Parker, On Greek Religion, Ithaca (NY) - London 2011.

PAULSEN 2003: T. Paulsen, «Verherrlichung und Verspottung. Die Gestalt des "Gottmenschen" bei Philostrat und Lukian», in G. Binder, B. Effe, R. Glei (eds), Gottmenschen. Konzepte existentieller Grenzüberschreitung im Altertum, Trier 2003, 97-120.

PETRIDOU 2015: G. Petridou, Divine Epiphany in Greek Literature and Culture, Oxford 2015.

Petrovic 2015: I. Petrovic, «Deification - Gods or Men?», in EIDINOW, KINDT 2015, 429-443.

PfeIJfFer 2005: I. L. Pfeijffer, «Propaganda in Pindar's First Pythian Ode», in K. A. E. Enenkel, I. L. Pfeijffer (eds), The Manipulative Mode. Political Propaganda in Antiquity: A Collection of Case Studies, Leiden - Boston 2005, 13-42.

PoHLEnZ 1952: M. Pohlenz, «Aristophanes' Ritter», Nachrichten der Akademie der Wissenschaften in Göttingen I. Philologisch-Historische Klasse 5 (1952), 95-128.

PULLEYN 1997: S. J. Pulleyn, Prayer in Greek Religion, Oxford 1997.

ReVermann 2006: M. Revermann, Comic Business: Theatricality, Dramatic Technique, and Performance Contexts of Aristophanic Comedy, Oxford 2006.

ReVermann 2014 : M. Revermann (ed.), The Cambridge Companion to Comedy, Cambridge 2014.

REVERMANN 2014: M. Revermann, «Divinity and Religious Practice», in REVERMANN 2014, 275-287. 
RöLlIG 1984: W. Röllig, s.v. 'Etana', in K. Ranke, H. Bausinger H. (eds), Enzyklopädie des Märchens: Handwörterbuch zur historischen und vergleichenden Erzählforschung iv, Berlin - New York 1984, 493-499.

Rosen 2014: R. M. Rosen, «The Comic Hero», in REVERMANN 2014, 222-240.

RuFFell 2011: I. A. Ruffell, Politics and Anti-Realism in Athenian Old Comedy: The Art of the Impossible, Oxford 2011.

RUTHERFORD 2013: R. B. Rutherford, Greek Tragic Style: Form, Language, and Interpretation, Cambridge 2013.

SATTLER 1962: P. Sattler, «Die Römer und dir Himmelstürmer: zu einem Epigramm des Alpheios von Mytilene in der Anthologia Palatina (Anth. Gr. 9.526)», in P. Sattler (ed.), Studien aus dem Gebiet der alten Geschichte, Wiesbaden 1962, 51-64.

SCHORN 2004: S. Schorn, Satyros aus Kallatis: Sammlung der Fragmente mit Kommentar, Basel 2004.

ScoTT 1932: K. Scott, «Humor at the Expense of the Imperial Cult», Classical Philology 27 (1932), 317-328.

SLATER 1988: W. J. Slater, «The Epiphany of Demosthenes”, Phoenix 42 (1988), 126-130.

SMITH 2011: A. C. Smith, Polis and Personification in Classical Athenian Art, Leiden - Boston 2011.

SOMMERSTEIN 1981: A. H. Sommerstein, Aristophanes: Knights, Warminster 1981.

SOMMERSTEIN 2005: A. H. Sommerstein, «A Lover of his Art: The Art-Form as Wife and Mistress in Greek Poetic Imagery», in E. Stafford, J. Herrin (eds), Personification in the Greek World: from Antiquity to Byzantium, Aldershot 2005, 161-171.

SOURVINOU-INWOOD 2003: C. Sourvinou-Inwood, Tragedy and Athenian Religion, New York - Oxford 2003.

STONEMAN 2007: R. Stoneman, «Introduzione», in R. Stoneman, T. Gargiulo (eds), Il Romanzo di Alessandro, vol. 1, Milan 2007, xv-lxxxviii.

STONEMAN 2012: R. Stoneman, «Commento: Libro II», in R. Stoneman, T. Gargiulo (eds), Il Romanzo di Alessandro, vol. 2, Milan 2012, 377-451.

TAEGER 1957: F. Taeger, Charisma. Studien zur Geschichte des antiken Herrscherkultes, vol. I, Stuttgart 1957.

TAPLIN 1977: O. Taplin, The Stagecraft of Aeschylus: The Dramatic Use of Exits and Entrances in Greek Tragedy, Oxford 1977.

THомAS 1988: R. F. Thomas, Virgil Georgics. Volume 2: Books III-IV, Cambridge 1988.

Thonemann 2005: P. Thonemann, «The Tragic King: Demetrios Poliorketes and the City of Athens», in O. Hekster, R. Fowler (eds), Imaginary Kings: Royal Images in the Ancient Near East, Greece and Rome, Stuttgart 2005, 63-86.

VERSNEL 2011: H. Versnel, Coping with the Gods: Wayward Readings in Greek Theology, Leiden 2011.

WEINREICH 1932: O. Weinreich, «Zu Virgils vierter Ecloge, Rhianos und Nonnos», Hermes 67 (1932), 359-363.

WEINREICH 1933: O. Weinreich, Menekrates Zeus und Salmoneus. Religionsgeschichtliche Studien zur Psychopathie des Gottmenschentums in Antike und Neuzeit, Stuttgart 1933 (reprinted in O. Weinreich, Religionsgeschichtliche Studien, Darmstadt 1968, 299-434). 
WeISS 1994: C. Weiss, s.v. Opora, LIMC VII.1 (1994), 55-58.

Whitman 1964: C. H. Whitman, Aristophanes and the Comic Hero, Cambridge (MA) 1964.

WINDISCH 1925: H. Windisch, «Friedensbringer-Göttersöhne: Eine religionsgeschichtliche Interpretation der 7. Seligpreisung», Zeitschrift für die neutestamentliche Wissenschaft und die Kunde der älteren Kirche 24 (1925), 240-260.

WRIGHT 2012: M. Wright, The Comedian as Critic: Greek Old Comedy and Poetics, London 2012.

\section{NOTES}

1. The terms "heroization" and "hero cult" can be justifiably used in a broad, inclusive sense, of the phenomenon of the ancient Greek worship of historical persons as a whole; for the holistic comprehension of this phenomenon, it is not always helpful to insist on a strict separation between divine and heroic cult: HABICHT 2017, 145-149, 206.

2. FARAONE 1997.

3. Compare TAEGER 1957, 107-108. The qualification "civic" is important; excluded thereby is e.g. Pheidippides as Strepsiades' personal "saviour" (Nub. 77, 1161-1162, 1177).

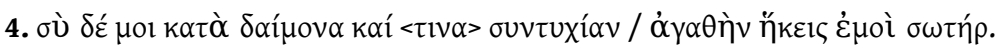

5. Peisetairos' bird-metamorphosis: Av. 654-655, 801-808.

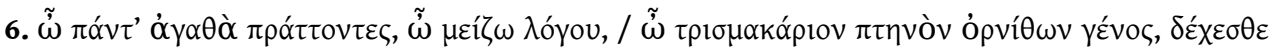

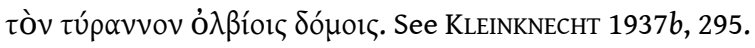

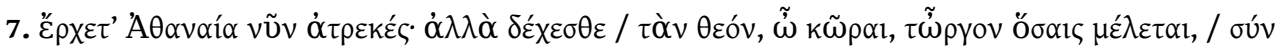

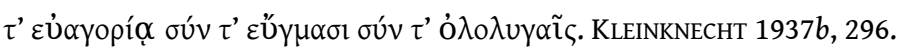

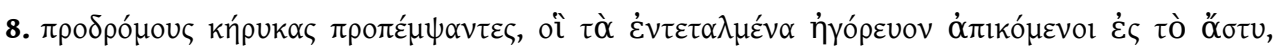

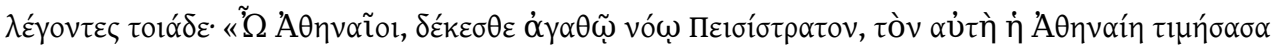

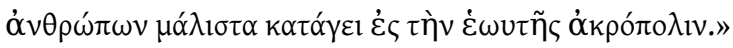

9. See DUNBAR 1995, 751-752.

10. Throughout I observe the convention of capitalizing the names of personified abstractions.

11. KaVOULAKI 1999, 314.

12. KAVOULAKI 1999, 314 instances Peleus at 'Hes.' fr. 211 Merkelbach-West.

13. On the eiselasis of the athletic victor, see CURRIE 2005, 139-140.

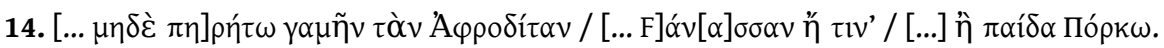

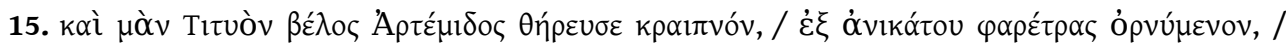

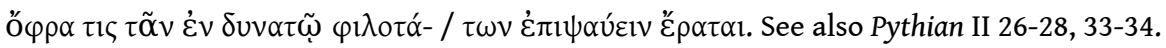

16. See WEINREICH 1932, 362; O'SULLIVAN 2008a; VERSNEL 2011, 452 and n. 58.

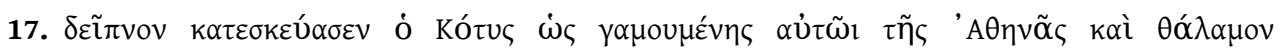

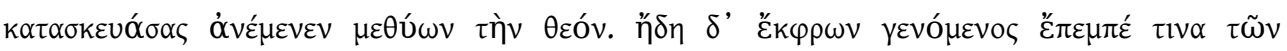

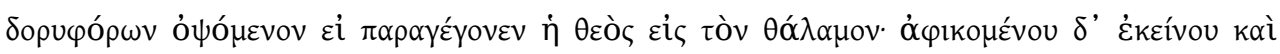

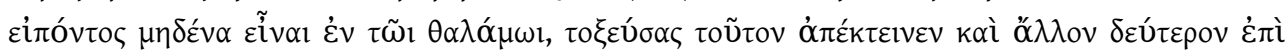

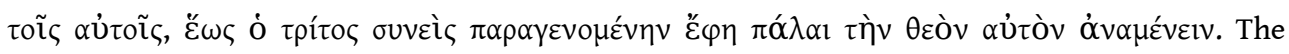
physical presence of the deity (hero) is presupposed in other stories of divine-human sexual intercourse (typically with genders reversed): the Hero of Temesa (Paus. VI 6.7-10), Astrabakos (Hdt. VI 69.1-4).

18. WeINREICH 1932, 361 (original in German). Compare KLEINKNECHT 1937b, 298, for marriage to a goddess as "die Krönung des Götterglücks, nach dem der Gottmensch strebt."

19. WEINREICH 1932. For the "saviour figure" or "divine man" in Virgil's Eclogues, see HARDIE 1998, 11-12, 20-22. 
20. BONNER 1943; VERSNEL 2011, 448 n. 40.

21. CURRIE 2016, 161-168.

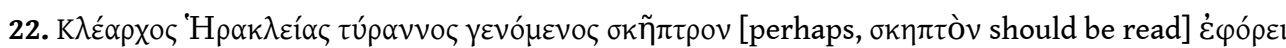

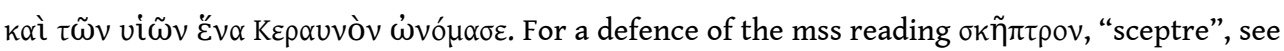
BURSTEIN 1974. See also VERSNEL 2011, 440.

23. $\alpha$ U่

24. KLEINKNECHT 1937b, 299; GRAF 2005. Cf. HABICHT 2017, 36, 113.

25. Cf. Ar. Vesp. 671, cf. 619-624; Cratinus frr. 73, 118, 258 Kassel-Austin. See BAKOLA 2010, 184 and n. 7. Zeus “tyranny” is used as an allegory for Perikles' political power in Cratinus' Plutoi (fr. 171.22-23 Kassel-Austin): BAKOLA 2010, 124-125 n. 24, 213. See KLEINKNECHT 1937b, 305; TAEGER 1957, 105, 108, 158-159.

26. See SCHORN 2004, 431-433, for the mischievous ambiguity in the question (thundering / farting).

27. On these coins, see e.g. LANE FoX 1996, esp. 100-102; Holt 2003, esp. 122-124, 151-152.

28. Caesar dum magnus ad altum / fulminat Euphraten. Cf. Hor. Carm. III 5.1-3. See ThомAs 1988, 240; HARDIE 1986, 51; differently, MYNORS 1990, 324. For the literary critical sense of "thunder" in a Roman context, see Prop. III 17.40. With Virgil's use of magnus, compare Plut. de Alex. magn. fort.

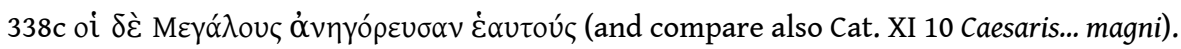

29. Compare CHANIOTIS 1997, 248 "from Hellenistic times on several references in literary sources and papyri indicate that stage-devices, similar to those used in the theater, were applied in mystery cults, to present flying gods, lightning and thunder, or give the astounded audience the impression that an earthquake was taking place."

30. See also SCHORN 2004, 431-432.

31. Cf. Rhesus 385 (Rhesos as Ares); cf. also 301. See FRIES 2014, 201, for Rhesus as a "saviour god." The adjective pavaĩoৎ (attested as an epithet of Apollo on Chios) is understood as "bringer of

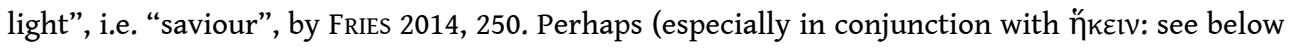

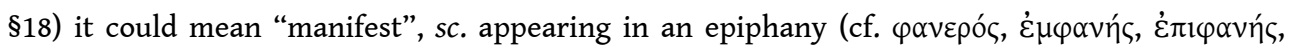

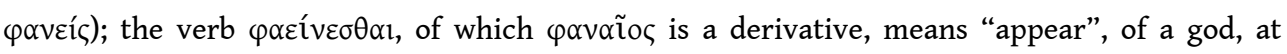
Callim. Hy. II 9.

32. CURRIE 2005,81 , cf. $45,198-199$. This view of the gnomai is found inadequate by HORNBLOWER 2008, 995-996. See also, however, VERSNEL 2011, 461-462.

33. See Nock 1928, 32 = 1972, i.146, on "the Pindaric habit of drawing parallels such as... Zeus defeating Typhon and Hieron defeating the Etruscans and their Carthaginian allies (Pyth. I)." Compare Cingano 1995, 18; PfeIJfFer 2005, 38-40.

34. See esp. KLEINKNECHT 1937b, 295-302; VERSNEL 2011, 484.

35. KLEINKNECHT 1937b, 296; CURRIE 2005, 181-183; CHANIOTIS 2011, 167-169.

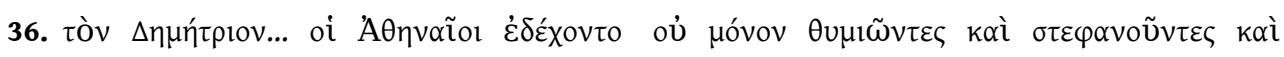

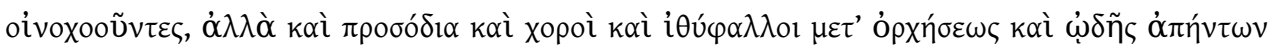
$\alpha \cup \dot{\tau} \tilde{\omega}$.

37. See PARKER 2011, 179-185.

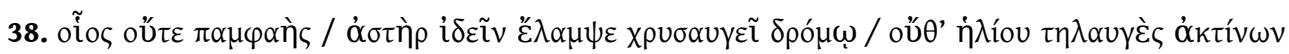

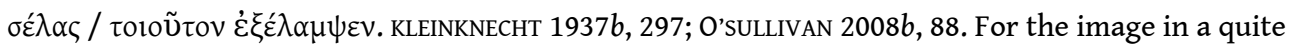
different encomiastic context, see Alcm. fr. 1.39-43 PMGF.

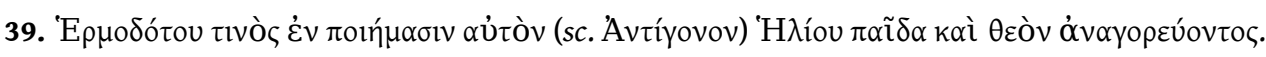

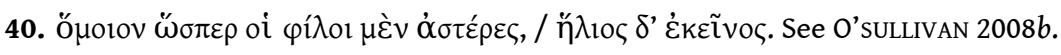

41. laudat Brutum laudatque cohortem, / solem Asiae Brutum appellat stellasque salubris / appellat comites excepto Rege; Canem illum, / invisum agricolis sidus, venisse. VERSNEL 2011, 448-449 n. 42.

42. CHANIOTIS 2011, 174-176. SLATER 1988, 127 n. 7. 
43. KLEINKNECHT 1937b; VerSNel 2011, 480-484. "Zooming" is the term used by SourvinOu-InWood 2003, 22-23, and often.

44. On the question of the identification of "Servant 1 " with the general Demosthenes, see OLSON 1992, 310 N. 22

45. SLATER 1988, 127, after KLEINKNECHT 1937b, 307; cf. TAEGER 1957, 107.

46. On the significance of the deictic, see SLATER 1988, 128.

47. It matters little for our purposes whether we read the $\theta \varepsilon \tilde{i} o v$ of the mss. and scholl. (defended by Pohlenz, followed by LANDFESTER) or Cobet's $\theta \varepsilon o ́ v$ (preferred by modern editors; cf. Plat. Leg. 682e10).

48. For the meaning "by the favour of a god", see scholl. Ar. Eq. 147a-c; cf. Pind. Ol. IX 28; LSJ s.v. katá B.v.

49. KLEINKNECHT 1937b, 307 n. 2. Cf. PULLeyn 1997, 138, 218.

50. See FEDELI 1983, 23 for discussion and further examples.

51. A quasi-heroic epiphany of Lamachos: KLEINKNECHT 1937a, 79 and n. 1; SLATER 1988, 127; CURRIE $2005,69$.

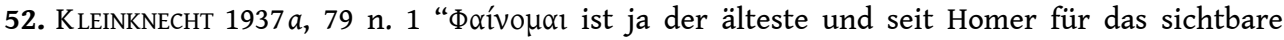
Kommen der Gottheit zu den Menschen gebräuchliche religiöse Begriff." Cf. LANDFESTER 1967, 36; Cf. SLATER 1988, 127. Cf. WhitMAN 1964, 102-103.

53. See CerfauX, Tendriau 1957, 185 n. 2 for comparison between Ar. Eq. 150 and the ithyphallic hymn to Demetrios, v. $18 \sigma \dot{\varepsilon} \delta \varepsilon \grave{\varepsilon} \pi \alpha \rho o ́ v \theta$ ' ó $\rho \tilde{\omega} \mu \varepsilon v$.

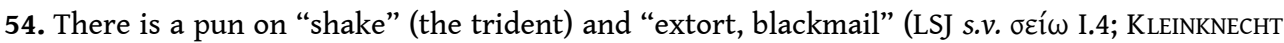
1937b, 310).

55. KLEINKNECHT 1937b, 310. Cf. SOMMERSTEIN 1981, 189.

56. With Eq. 840, cf. Av. 1752.

57. For the Sausage-Seller as hierokēryx, see KLEINKNECHT 1939, 59 (cf. KLEINKNECHT 1937b, 295-297, for the ritual of good-news bringing); LANDFESTER 1967, 92; SLATER 1988, 129.

58. KLEINKNECHT 1937b, 301; 1939, 59 and n. 3.

59. KLEINKNECHT 1939.

60. KleinKNeCht 1937b, 300; 1939, 61; PetRIDOU 2015, 37.

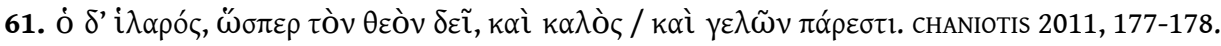

62. On BASILEIA as divine, compare VERSNEL 2011, 483 n. 135. For BASILEIA as an "ephemeral personification", without any known cults (she is also depicted on an Athenian pyxis of 420-410 BCE), see SMITH 2011, 83-84 (a reference for which I thank Prof. G. Camassa). For OPORA as divine, note her presence on Attic red-figure vases of 420-400 BCE in the company of Dionysos (WEISS 1994; SMITH 2011, 79-81). Compare DIALLAGE at Ar. Lys. 1114 (a reference I owe to Constanze Güthenke). The fact that SPONDAI and DIALLAGE in their respective plays are bestowed by human characters on human characters makes it harder to conceive of them as divine (Trygaios has OPORA and THEORIA from the gods: Pax 706-707, 847).

63. See KleinKNeCHT 1939b, 65 and n. 1; KRON 1979, 71-72; AlEXANDRI-TZAHOU 1986, 375; GLOWACKI 2003; SMITH 2011, 96-97.

64. KLEINKNECHT 1939b, 58-59.

65. TAEGER 1957, 107.

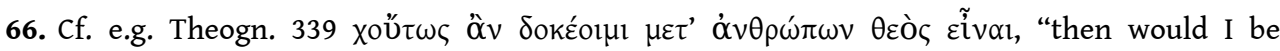
considered a god among men."

67. Compare WHITMAN 1964, 103.

68. CURRIE 2012, 336, 338.

69. I dispense with discussion of the third passage (Pax 1033-1038).

70. The third time is Pax 1033-1038. 
71. For the term in the context of ruler-cult, compare НАВісHТ 2017, 150-151.

72. KLEINKNECHT 1937b, 307 n. 4 "[der Begriff sōtēr hat] bei Aristophanes im Bezug auf Götter und Menschen schon deutlich die soteriologische, religiös-politische Beduetung." See in general DORNSEIFF 1927, 1212.4-9 "[sōtēr ist] für den Griechen älteren Zeit auf die hohe religiöse Sprache beschränkt. Man greift zu diesem Wort nur gegenüber Übermenschlichem”, 1213.37-38 "Auf Menschen angewandt bedeutet die Bezeichnung [sōtēr] fast eine Heroisierung." Cf. НАBICHT 2017, 113. Differently, Nock 1951, 127 = 1972, ii.720 "when applied to [men], [sōtēr] did not necessarily suggest that they belonged or approximated to the category of the [gods]"; JoNEs 2010, 26 "[the term sōtêr] does not need to imply divinity, and is sometimes no more than a polite way of addressing a superior." See also JIM (forthcoming).

73. OlSON 1998, 244. Cf. TAEGER 1957, 107.

74. On this phrase, see FinGLASS 2018, 172 (rather than JEBB 1893, 13). For altars in ruler-cult, see HABICHT 2017, 101-102 (to Lysandros in Samos: Duris, in Plut. Lys. 18.5; to Demetrios in Athens: Plut. Demetr. 10.5, Clem. Al. Protr. 4.54.6).

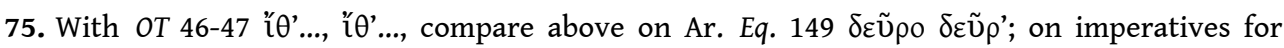
"come" in prayers, see PULLEYN 1997, 136-144, 219. For OT 35-39 as evidencing the da-quia-dedisti form typical of prayers (PULLEYN 1997, 17), see Finglass 2018, 178.

76. BARTOL 2016, 515, 516 n. 89.

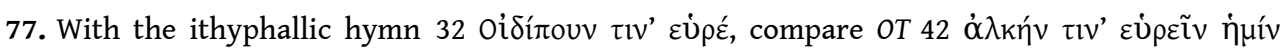
(BARTOL 2016, 517).

78. For prayers to powerful individuals in the fifth and fourth centuries BCE, see CURRIE 2005, 180 . 79. BARTOL 2016, 515-516 sees more of a contrast between the divinity of the Demetrios of the ithyphallic hymn and the humanity of the Oidipous of the Oedipus Tyrannus.

80. LeVene 1997, 89. See, similarly, Habicht 2017, 142-145; Petrovic 2015, 433.

81. See in general CURRIE 2005, 158-200, esp. 187.

82. See WINDISCH 1925, 251-257, esp. 253 (citing, inter alia, Ev. Matt. V 9; Dio XLIV 49.2, LXXII 15.5); Cerfaux, Tendriau 1957, 185; Versnel 2011, 450.

83. See SATTLER $1962,56$.

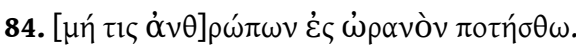

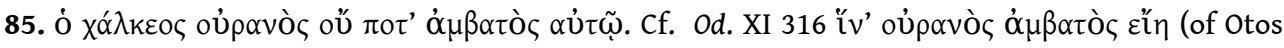
and Ephialtes).

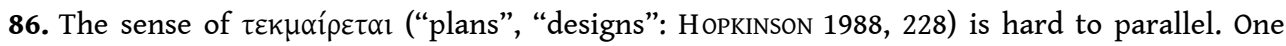

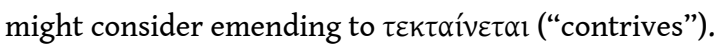

87. Cf. Curt. IV 7 immortalitatem adfectantem, of Alexander the Great "aspiring to immortality."

88. SATTLER 1962, 52-58 interprets the epigrams as ironic characterizations of Rome's arrogance.

89. For the figurative sense, cf. also Hor. Carm. I 1.4-6; Epist. I 17.34; note also Carm. I 3.38-40.

90. STONEMAN 2012, 444-447. On recension L, see STONEMAN 2007, lxxix-lxxx.

91. STONEMAN 2012, 440 "Il desiderio di immortalità di Alessandro è un leitmotiv del Romanzo"; STONEMAN 2007, lxiii-lxiv.

92. For Etana in the king-list, see GLASSNER 2004, 121. For the poem Etana, see HAUL 2000.

93. RÖLLIG 1984, 497; HAUL 2000, 44-47; HENKELMAN 2006, 843.

94. On receptions of Etana in Greece, see CURRIE (forthcoming).

95. OLSON 1998, 81.

96. DOVER 1968, 125-126 "Socrates is looking down on Strepsiades as a god might look down from

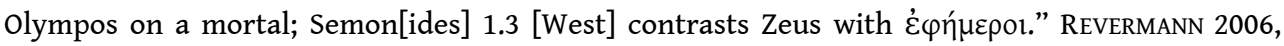
196-197; cf. TAEGER 1957, 106. See also WRIGHT 2012, 112, for a different dimension to the scene.

97. HARDIE 1986, 194-195, 209-212, cf. 37-38.

98. REVERMANN 2006, 197 n. 40. 
99. See HUNTER 2004, 65 on "the literalization of metaphorical language" in Old Comedy.

100. See above on the metapoetic dimension to Perikles "thundering" and the metatheatrical dimension to Sokrates in the mēchane.

101. Compare in general KLEINKNECHT 1937b, 295 n. 1.

102. On chariot entrances in tragedy, see TAPLIN 1977, 76-78.

103. Cf. Pax 1043-1044, 1208-1209; etc.

104. Compare PoHLEnZ 1952, 109. See, in general, Finglass 2018, 191.

105. See FEDELI 1983, 23.

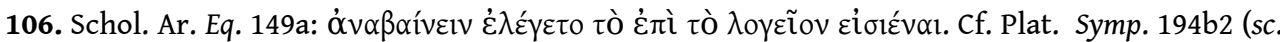

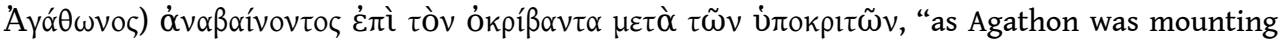
the stage/tribune with the actors." KLEINKNECHT 1937b, 308.

107. KLEINKNECHT 1939, 62-63 "Das Sehen ist ja natürlich ein bei der Parusie ganz wichtiger Begriff."

108. SOMMERSTEIN 1981, 215 "this is the first appearance of what became a cliché in later comedy, the creaking door as a sign that someone was about to emerge from the skène."

109. Kanavou 2011, 98-99.

110. RUTHERFORD 2013, 3-4, 100-101.

111. Cf. KleINKNECHT 1939, 58 n. 5, 61, 65; KLEINKNECHT 1937b, 309, 310; SLATER 1988, 128-129.

112. REVERMANN 2014, 286.

113. See CURRIE 2012, 341-342.

114. Compare similarly Diod. XVI 11.1, on Dion at Syracuse.

115. RUFFELL 2011, 210-211.

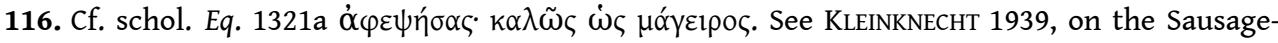
Seller and DEMOS; KAVOULAKI 1999, 317-318; RUFFELL 2011, 208.

117. See, on Pindaric epinician, CURRIE 2005, passim; and on Sophoclean tragedy, CURRIE 2012, esp. 343.

118. On the term "comic hero", see WhitMan 1964; Rosen 2014.

119. See especially WHITMAN 1964, 103, 116, 196; compare TAEGER 1957, 107-108.

120. SCOTT 1932

121. See PAULSEN 2003.

122. On Peisetairos and Peisistratos, see B ONNER 1943; B OWIE 1993, 165; KaVoulaKi 1999, 317; Petridou 2015, 169-170; Versnel 2011, 448 n. 40, 483 n. 135; but see also, against, KanAVou 2011 $108 \mathrm{n}$. 478. The form of Aristophanes' protagonist's name attested in the ancient transmission is Peisthetairos and (in a scholium) Pisthetairos; modern corrections are Peithetairos and (the preferable) Peisetairos: DunBAR 1995, 128-129; KANAvou 2011, 105-107.

123. VERSNEL 2011, 441.

124. Compare SCOTT 1932, 328; VERSNEL 2011, 467, 476.

125. VeRSNEL 2011, 442, 471-476. In general, on the "theatricality" of public life in ancient Greece, see CHANIOTIS 1997 (focussing on the Hellenistic period; on the pre-Hellenistic period, note esp. ibid. 220, 223, 249; OBER 1989, 154-155; SLATER 1988).

126. CHANIOTIS 1997, 235-238, 238-242.

127. VERSNEL 2011, 442.

128. For contrasting assessments of how shocking this performance was, see LANE FoX 1973, 20 and HORNBLOWER 2011, 281.

129. Chaniotis 1997, 238-239, 2011, 163-164; THONEMANn 2005, esp. 73-74, 78-79, 82-84.

130. CHANiOTis 1997, 241-242, on Antonius' theatricality.

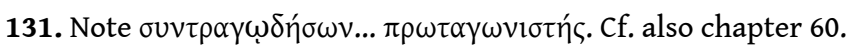


132. CONNOR 1987, 44 "The populace joins in a shared drama..."; CHANIOTIS 1997, 223. For another possible early-fifth-century heroizing "drama" (involving Euthymos of Locri and the Hero of Temesa), see CURRIE 2002, 39.

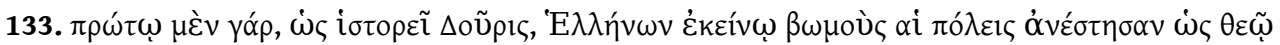

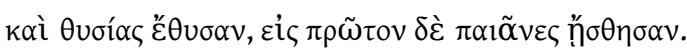

134. Compare TAEGER 1957, 108.

135. Pace e.g. KAVOULAKI 1999, 313-314; REVERMANN 2012, 285.

136. See above. Intriguing is the statement made about the generals of the past in an unidentified

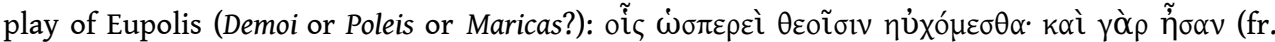
384.6 Kassel-Austin).

137. Contrast e.g. НАвіснт 2017, 1 n. 1 "Duris explicitly calls Lysander the first Greek to receive divine honors"; similarly, CHANIOTIS 2003, 434.

138. Cf. Od. XVI 386 (Telemachus for the transformed Odysseus).

139. For iuuenis of Octavian, cf. Geo. I 500.

140. For these as private, not civic, offerings to Augustus, compare BRINK 1982, 55.

141. On the state's tolerance of privately-initiated cults, see GARLAND 1992, 75; PARKER 2005, 65-68; ANDERSON 2015, 311. Cf. CURRIE 2005, 5-6.

142. TLL VI.3.2924.61-2925.22. Cf. Hor. Epist. II 1.15.

143. For Ephorus as dealing with the episode, cf. Plut. Alc. 32.2. On Justin's (Trogus') relationship to Ephorus here, compare НABICHT 2017, 4-5.

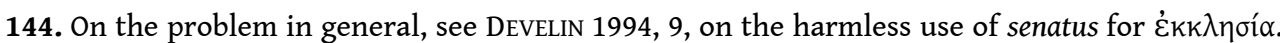
TAEGER 1957, 159 n. 36 regards Justin's [sc. Alcibidem] quasi de caelo missum (V 4.10) as the kind of Romanization that makes Justin's (Trogus') report "utterly worthless" (for the saviour sent from heaven in Roman contexts, cf. Hor. Carm. I 2.45, with the parallels cited by NISBET, HUBBARD 1970, 37, including Plut. fort. Alex. 330d; note also Virg. Geo. I 503-504; etc.). But the essential idea in quasi de caelo missum is not so different from that implied at Hdt. VII 56.2 (Zeus on earth in the guise of Xerxes), and even if this is a Romanization, it does not entail that Justin (Trogus) also invented Alkibiades' receiving "divine honours."

145. НАВICHT 2017, 4.

146. Justin's phrase ciuitas uniuersa, "the whole populace" (V 4.10; cf. Diod. XIII 68.2 ò $\delta \tilde{\eta} \mu \circ$ ö $\pi \alpha$; Nepos Alc. 6.1 uniuersa ciuitas), clearly intends the Athenians in a non-civic capacity.

147. Compare F LOWER 1988, 126-127, challenging H ABICHT's parallel argument about the significance of Xenophon's silence about the Thasians' offer of deification to Agesilaos.

148. Hic ut e naui egressus est, quamquam Theramenes et Thrasybulus eisdem rebus praefuerant simulque uenerant in Piraeum, tamen unum omnes illum prosequebantur, et, id quod numquam antea usu uenerat nisi Olympiae uictoribus, coronis laureis taeniisque [transmitted: aureis aeneisque] uulgo donabatur.

149. Plutarch also claims that Perikles was treated this way by Athenian women in 439 BCE (Per. 28.5).

150. Xen. HG II 4.12-20; Diod. XIII 68-69; Plut. Alex. 32-33; Athen. XII 535c.

151. Thucydides' descriptions of Brasidas' treatment at Scione and posthumous hero cult at Amphipolis are exceptional in his History (HORNBLOWER 1996, 449); Thucydides in general plays down popular religious elements (HORNBLOWER 2011=1992).

152. Compare TAEGER 1957, 163; contrast HABICHT 2017, 2.

153. e.g. TAEGER 1957, 162-163; see, for discussion, HABICHT 2017, 2 n. 5, 179, 209; and, in particular, VERSNEL 2011, 456-457. Confirmation of Duris' testimony of a Lysandreia festival on Samos, and its association with Hera, is provided by IG XII.6 1:334: see HABICHT 2017, 179; HALLOF 2000, 256-257.

154. Another controversial and isolated claim is Plutarch's story that Agesilas declined the divine cult that the Thasians offered him in (probably) 394 BCE (Sayings of Spartans 210c-d). H ABICHT 2017, 132 objected: "There is... no evidence whatsoever that a Greek ever refused divine honors 
offered to him.... It seems that only the Romans, not the Greeks, had such religious scruples." But for something like this religious scruple in the mid-fifth century BCE, compare Aesch. Ag. 925

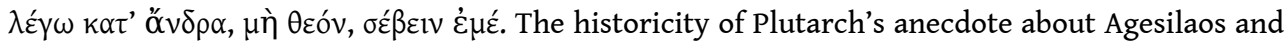
the Thasians is defended by FLOWER 1988.

155. See CURRIE 2005, 163-174 (on Hagnon at Amphipolis and Euthymos at Locri).

156. The significance of Aristophanes is well recognized by KLEINKNECHT $1937 b$ and 1939. It is undervalued by e.g. Nock 1951, 130 n. $10=1972$, ii.722 n. 10.

157. See CURRIE 2005, 285-288, with 261-275. Differently, MORGAN 2015, 177, 179, who, however, refrains from making holistic sense of the evidently overlapping historical circumstances presupposed by all of Pindar, Py. II 18-20; the scholia to Pindar, Py. II 36c and 38; and Justin XXI 3.2.

\section{ABSTRACTS}

Aristophanes' Knights, Peace, and Birds are deeply interested in the figure of the civic "saviour", who is depicted as a Gottmensch: a man become god or, at least, a man deserving of religious treatment such as the gods receive. While the Aristophanic treatment of the theme contains many parodic, paratragic, and metatheatrical elements, it arguably still offers a utilizable and unique window onto real-life practices concerning fifth-century BCE Gottmensch- and saviourfigures. Aristophanic comedy consequently has a role to play in the reconstruction of the early history of saviour- and ruler-cult, prior to the divine cult given to Lysandros in his own lifetime at Samos in 404 BCE.

I Cavalieri, la Pace e gli Uccelli di Aristofane sono commedie da cui emerge un profondo interesse verso la figura del "salvatore" civile, che viene raffigurato come un Gottmensch: un uomo che diventa dio o, quanto meno, un uomo reputato meritevole di ricevere onori religiosi come quelli che si tributano agli dei. Benché questo tema presso Aristofane contenga molti elementi parodici, paratragici e metateatrali, esso probabilmente apre ancora una finestra utile e unica sulle pratiche della vita quotidiana riguardanti le figure del Gottmensch e del salvatore del V secolo a.C. La commedia aristofanea può quindi svolgere un ruolo importante nella ricostruzione del culto del salvatore e del sovrano nel periodo precedente al culto divino, a Samo nel 404, a.C.conferito a Lisandro quando era ancora in vita

\section{INDEX}

Keywords: Aristophanes, saviour cult, Gottmensch, ruler-cult, epiphany

Parole chiave: Aristofane, culto del salvatore, Gottmensch, culto del sovrano, epifania 
AUTHOR

\section{BRUNO CURRIE}

Mason Monro Fellow and Tutor in Classics

Oriel College

Oxford OX1 4EW

United Kingdom

bruno.currie(at)oriel.ox.ac.uk 